Article: Extinction-related Angström exponent characterization of submicrometric volume fraction in atmospheric aerosol particles

Authors: A. Quirantes, J.L. Guerrero-Rascado, D. PérezRamírez, I. Foyo-Moreno, P. Ortiz-Amezcua, J. A. Benavent-Oltra, H. Lyamani, G. Titos, J.A. Bravo-Aranda, A. Cazorla, A. Valenzuela, J.A. Casquero-Vera, A.E. Bedoya-Velásquez, L. Alados-Arboledas, F. J. Olmo

Journal: Atmospheric Research

Volume: 228

Pages: $\mathbf{2 7 0 - 2 8 0}$

Year: 2019

DOI: 10.1016/j.atmosres.2019.06.009 


\title{
EXTINCTION-RELATED ANGSTRÖM EXPONENT CHARACTERIZATION OF SUBMICROMETRIC VOLUME FRACTION IN ATMOSPHERIC AEROSOL PARTICLES
}

\author{
A. Quirantes ${ }^{1,2}$, J.L. Guerrero-Rascado ${ }^{1,2}$, D. Pérez-Ramírez ${ }^{1,2}$, I. Foyo-Moreno ${ }^{1,2}$, P. Ortiz- \\ Amezcua $^{1,2}$, J. A. Benavent-Oltra ${ }^{1,2}$, H. Lyamani ${ }^{1,2}$, G. Titos ${ }^{1,2}$, J.A. Bravo-Aranda ${ }^{1,2}$, A. \\ Cazorla $^{1,2}$, A. Valenzuela ${ }^{1,2}$, J.A. Casquero-Vera ${ }^{1,2}$, A.E. Bedoya-Velásquez ${ }^{1,2,3}$, L. Alados- \\ Arboledas $^{1,2}$, F. J. Olmo ${ }^{1,2}$ \\ ${ }^{1}$ Dpt. Applied Physics, Faculty of Sciences, University of Granada, Fuentenueva s/n, 18071, \\ Granada, Spain \\ ${ }^{2}$ Andalusian Institute for Earth System Research (IISTA-CEAMA), Avda. delMediterráneo s/n, 18006, \\ Granada, Spain \\ ${ }^{3}$ Sciences Faculty, Department of Physics, Universidad Nacional de Colombia, Medellín, Colombia
}

\begin{abstract}
The $\mathrm{AE}_{\mathrm{AOD}}-\triangle \mathrm{AE}_{\mathrm{AOD}}$ grid proposed by Gobbi et al. (2007) is a graphical method used to visually represent the spectral characterization of aerosol optical depth (AOD), i.e. Angström exponent (AE) and its curvature, in order to infer the fine mode contribution ( $\eta$ ) to the total AOD and the size of the fine mode aerosol particles. Perrone et al. (2014) applied this method for the wavelengths widely used in lidar measurements. However, in neither case does the method allow for a direct relationship between $\eta$ and the fine mode fraction contribution to the total aerosol population. Some discussions are made regarding the effect of shape and composition to the classical AE$\triangle \mathrm{AE}$ plot. The potential use of particle backscatter measurements, widely used in aerosol characterization methods together with extinction measurements, is also discussed in the $\mathrm{AE}-\triangle \mathrm{AE}$ grid context. A modification is proposed that yields the submicron contribution to the total volume concentration by using particle extinction data, and a comparison to experimental measurements is made. Our results indicate that the use of a modified $\mathrm{AE}-\triangle \mathrm{AE}$ grid plot to directly obtain submicrometric and micrometric mode fraction to the total aerosol population is feasible if a volume-based bimodal particle size distribution is used instead of a number-based one.
\end{abstract}

Keywords: lidar; aerosol; graphical method; submicrometric fraction 


\section{INTRODUCTION}

The aerosol particles constitute a key climate forcing factor due to their impact on the radiation balance of the Earth-atmosphere system. Thus, the monitoring of the aerosol evolution of their optical and microphysical properties, and also their transport in the atmosphere, becomes essential in order to get a reliable prediction of global climatic and environmental changes all over the world. In order to estimate these impacts, a large variety of methods for monitoring atmospheric aerosols were developed. Among others, remote sensing methods, both active and passive, proved to be fruitful and convenient. A variety of procedures to retrieve aerosol microphysical particles from passive remote sensing measurements were developed in the 70s (e.g. Herman et al., 1971; Shaw et al., 1973, 1979), and applied to sun-photometry measurements in the 90s (Nakajima et al., 1996). Retrieval of column-integrated properties were successfully applied to ground-based networks such as AERONET (Dubovik and King, 2000; Dubovik et al., 2006). Further developments in retrieval techniques allowed to retrieve column-integrated aerosol microphysical properties from space polarimetry measurements (e.g. Dubovik et al., 2011).

Retrieval of aerosol microphysics vertical-profiles is possible through the inversion of multiwavelength lidar measurements. The first such approach is based on measurements from two extinction $(\alpha)$ and three backscatter $(\beta)$ coefficients, the socalled $3 \beta+2 \alpha$ configuration, and the inversion scheme is based on regularization (Müller et al. 1999a,b; Veselovskii et al., 2002). Inversion by regularization yields aerosol physical parameters such as effective radius, volume, surface-area, and number concentrations, with uncertainties between 20-30 \% (Pérez-Ramírez et al., 2013). Retrievals of complex refractive index are also possible although with large uncertainties \pm 0.05 for real part and $\pm 100 \%$ for imaginary part (e.g. Müller et al., 1999a,b; Veselovskii et al., 2002). The inversion by regularization has proved to be feasible for large fine mode populations, although errors in the retrieved properties increase as preponderance of the coarse mode grows (e.g. Whiteman et al., 2018). The large uncertainties and the limitations of the retrieval process to certain aerosol types are explained by the lack of enough information for solving the ill-posed problem of lidar inversion (Mishchenko et al., 2016). The problem of insufficient information content in the $3 \beta+2 \alpha$ retrievals is common to different techniques (e.g. Burton et al., 2016). 
To address the limitations on the $3 \beta+2 \alpha$ retrievals, additional approaches were used, such as using non-spherical kernel functions for dust retrieval (e.g. Veselovskii et al., 2018) or using optimized constraints for single scattering albedo (Pérez-Ramírez et al., 2019). An alternative method was proposed by Gasteiger et al. (2011), which combined particle extinction, backscatter and depolarization profiles $(3 \beta+2 \alpha+2 \delta)$ to obtain concentration values of ash particles in the atmosphere. Instead of using a regularization method, their proposal was based on a statistical approach, where a set of aerosol ensembles of monomodal, spheroidal particle distributions was found to be comparable to experimental particle populations within experimental uncertainty. This approach was also tested in the absence of depolarization measurements (Quirantes et al., 2012). However, all these methods require good signal-to-noise ratio in the lidar signals, which is feasible in very sophisticated High Spectral Resolution Lidar and Raman lidar using high-power laser beams. Lidar networks such as EARLINET (Pappalardo et al., 2014) and LALINET (Guerrero-Rascado et al., 2016) do not typically run many of these highly sophisticated systems, which limit network monitoring of aerosol microphysics vertical-profiles capabilities mostly to night-time hours (e.g. Müller et al., 2016).

The limitations of $3 \beta+2 \alpha$ retrievals encouraged the development of methods that includes additional measurements, and in the framework of EARLINET network the synergic combination of lidar with other instruments such as sun photometry or moon/star photometers is the most extended approach. The LIRIC (Lidar Radiometer Inversion Code - Chaikovsky et al, 2012, 2016) algorithm relies on layer-by-layer aerosol optical information contained in three lidar elastic backscattered signals plus aerosol microphysical information contained in column-integrated direct Sun and sky radiance measurements previously retrieved by AERONET sun-photometers (Holben et al., 1998). The LIRIC approach can estimate profiles of fine and coarse aerosols volume concentration, discriminating between spherical coarse and spheroidal coarse scatterers when depolarization lidar measurements are provided as input. On the other hand, the GARRLiC (Generalized Aerosol Retrieval from Radiometer and Lidar Combined data Lopatin et al., 2013) scheme uses LIRIC heritage but includes inversion of both the coincident lidar (range-corrected signal) and the Sun-sky photometer measurements (AOD and sky radiances), in order to obtain not only vertically-resolved but also 
column-integrated aerosol optical and microphysical properties such as single scattering albedo and refractive index for both fine and coarse modes separately.

Retrieving aerosol microphysical properties through remote sensing techniques is a highly sophisticated task that requires dealing with a wide range of different problems, both physical and mathematical (Osterloh et al., 2013). To overcome such complexity an alternative, graphical method was proposed by Gobbi et al. (2007), first applied to Sun-photometric data and then used on to vertically-resolved lidar signals (Perrone et al., 2014).

An additional limitation of all the inversion schemes for the retrieval of aerosol microphysical properties from multiwavelength measurements is the requirement of complex mathematical codes. As each group typically develops their own code, there is no common standard. The GRASP code (Generalized Retrieval of Atmosphere and Surface Properties - Dubovik et al., 2014) is trying to overcome all these problems but still very little can be done to minimize the complexity of the numerical environment. To address all limitations, estimates of size distribution properties can be obtained through the analysis of the spectral dependence of the Angström parameter. Such analyses are straightforward when compared with a typical inversion of an ill-possed problem (e.g. O’Neill et al., 2001), although the number of retrieved parameters is considerable lower. Similarly, the graphical method proposed by Gobbi et al., (2007) hereafter referred as Gobbi/like grid plots - yields a graphical estimation of fine mode contribution to aerosol optical depth and fine mode radius. Such approach has been successfully used to analyze different aerosol types using sun-photometry data (e.g. Valenzuela et al., 2014) or to study day-to-night columnar aerosol properties (e.g. Pérez-Ramírez et al., 2012), and also particle populations in industrial flares (GuerreroRascado et al., 2014). Further adaptations of the Gobbi/like grid plots are used for lidar data (e.g. Perrone et al., 2014) with some limitations of backscattering when dealing with non-spherical particles.

The objective of this work is to make a sensitivity analysis of a Gobbi/like grid plot under different assumptions for non-spherical particles. The ALPHA database (Quirantes et al., 2010), calculated by means of the T-Matrix theory, is used. Changes in the Gobbi/like grid plots are suggested to obtain direct estimation of particle volume in both fine and coarse modes. Section 2 describes the details of the experimental setup used to retrieve AOD data. A brief description of the Gobbi plot and its dependence on 
AOD is included in Section 3. The feasibility of our modified Gobbi approach is discussed in Section 4. Summary and conclusions are given in the last section.

\section{EXPERIMENTAL SITE \& INSTRUMENTATION}

The experimental data used in this study were acquired at IISTA-CEAMA station, located at Granada, southeastern Spain $\left(37.16^{\circ} \mathrm{N}, 3.61^{\circ} \mathrm{W}, 680 \mathrm{~m}\right.$ a.s.l.). Granada is a non-industrialized, medium-sized city located in a natural basin surrounded by mountains with altitudes of up to $3400 \mathrm{~m}$ a.s.l. in the East region (Sierra Nevada mountain range). This region is characterized by its complex terrain surrounded by mountains, mainly affected by Mediterranean continental climate conditions. The region has cold winters (mean daily maximum temperature: $10.6 \pm 1.1^{\circ} \mathrm{C}$ ), and dry/hot summers (mean daily maximum temperature of $28.8 \pm 0.9^{\circ} \mathrm{C}$, mean daily maximum of surface RH up to $55.0 \pm 6.0 \%$ ) at surface level (Bedoya-Velásquez et al., 2019). Due to its location in the southwestern Mediterranean, the area is affected by different airmasses coming from Africa, the Atlantic Ocean, the Mediterranean and inland the Iberian Peninsula and Europe (e.g. Pérez-Ramírez et al., 2016). Such air-mass patterns explains why long-range transport of aerosol is predominantly affected by mineral dust particles from the African continent (Lyamani et al., 2006 a, b; Guerrero-Rascado et al., 2011; Córdoba-Jabonero et al., 2011; Titos et al., 2012; Navas-Guzmán et al., 2013a; Valenzuela et al., 2014; Cazorla et al., 2017). Smoke advected principally from surrounded regions, Europe, Northern Africa, and the Iberian Peninsula, also affect the region (e.g. Lyamani et al., 2006a,b), with some long-range transport from North America (e.g. Ortiz-Amezcua et al., 2017). The region has been also reached by extraordinary aerosol events such as volcanic plumes (Navas-Guzmán et al., 2013b). Granada is also influenced by local anthropogenic sources such as traffic and domestic heating in wintertime (Titos et al., 2017). All these different situations make aerosol over Granada very variable and complex, thus making the region attractive to test any development in remote sensing retrievals (Moreira et al., 2018).

The instruments used in this study are described as follows. The Sun-photometer CE-318-4, included in the AERONET network (Holben at al., 1998), is used for column-integrated characterization of the atmospheric aerosol. This instrument takes direct sun measurements with a $1.2^{\circ}$ full field of view at 340, 380, 440, 675, 870, 940, and $1020 \mathrm{~nm}$. The full-width at half-maximum of the interference filters are $2 \mathrm{~nm}$ at 340 
$\mathrm{nm}, 4 \mathrm{~nm}$ at 380 and $10 \mathrm{~nm}$ at all other wavelengths. Solar extinction measurements are used to obtain aerosol optical depth at each wavelength except at $940 \mathrm{~nm}$, which is used to retrieve total column water vapour. A complete description can be found in Holben et al. (1998).

The multi-wavelength Raman lidar MULHACEN (Raymetrics S. A., Greece) is included in EARLINET (European Aerosol Lidar NETwork) (Pappalardo et al., 2014) and also in SPALINET (Spanish and Portuguese Aerosol Lidar Network) (Sicard et al., 2009). This lidar system emits laser pulses at 1064, 532 (parallel and perpendicular polarization channels) and $355 \mathrm{~nm}$, and receives backscattered radiation at the same wavelengths as well as Raman-shifted backscattered radiation at 607 and $387 \mathrm{~nm}$ from $\mathrm{N}_{2}$ molecules and at $408 \mathrm{~nm}$ from $\mathrm{H}_{2} \mathrm{O}$ molecules. Atmospheric information retrieved from lower regions is limited by the full overlap height, which is reached above $1.3 \mathrm{~km}$ a.s.l. due to the system configuration (Guerrero-Rascado et al., 2010). In this work only segments of the profile unaffected by incomplete overlap are considered. The vertical resolution and temporal resolution for lidar backscattered signals is $7.5 \mathrm{~m}$ and $1 \mathrm{~min}$, respectively. A full description of this instrument can be found in Guerrero-Rascado et al. (2008.

\section{METHODOLOGY}

\subsection{Columnar data}

The spectral dependence of the aerosol optical depth (AOD) can be evaluated through the Angström exponent, $\operatorname{AE}_{\mathrm{AOD}}\left(\lambda_{1}, \lambda_{2}\right)$, defined as:

$$
A E_{A O D}\left(\lambda_{1}, \lambda_{2}\right)=-\frac{\ln \left(A O D_{\lambda_{2}} / A O D_{\lambda_{1}}\right)}{\ln \left(\lambda_{2} / \lambda_{1}\right)}
$$

Similarly, the Angström exponent for scattering, absorption, and backscatter can also be defined. $\mathrm{AE}_{\mathrm{AOD}}$ is a good indicator of the dominant size of the scattering particles in the atmosphere (Angström, 1929). In general terms, values above 1 are typically related to contributions of fine-mode aerosols $\left(\mathrm{AE}_{\mathrm{AOD}}=4\right.$ in the Rayleigh limit), while $\mathrm{AE}_{\mathrm{AOD}}$ values lower than 1 are associated with a large presence of coarse (micronsized) particle populations (Kaufman, 1993). However, while large $\mathrm{AE}_{\mathrm{AOD}}$ values can be directly associated to small particles, the case for small $\mathrm{AE}_{\mathrm{AOD}}$ is not straightforward. 
Aerosol populations in nature are mostly modelled by a bi-modal distribution. For instance, a Saharan dust layer advected over an urban/industrial region is a bimodal particle population from the columnar point of view, with an underlying layer composed by a fine mode of anthropogenic particles and a lofted layer composed by coarse mode of mineral particles (Valenzuela et al. 2014). Nevertheless, a low $\mathrm{AE}_{\mathrm{AOD}}$ value can be attributed to a combined population of large and small modes as well as to a large mode only (i. e. pure Saharan dust layer over desertic regions).

The information contained in $\mathrm{AE}_{\mathrm{AOD}}$ allows for extracting information about the submicrometer component of a two-mode aerosol population (O'Neill et al. 2001). Since the total AOD is the sum of the fine- and coarse-mode optical depths, the full $\mathrm{AE}_{\mathrm{AOD}}$ can be written as:

$$
A E_{A O D}=A E_{A O D, f} \cdot \eta+A E_{A O D, c} \cdot[1-\eta]
$$

where $\eta=A O D f / A O D$ is the relative contribution of the fine mode to the AOD. Eq. (2) can be exploited to solve for $\mathrm{AE}_{\mathrm{AOD}}$ in terms of measurable quantities under the assumption that the coarse-mode Angström exponent ( $\left.\mathrm{AE}_{\mathrm{AOD}}\right)$ is zero or close to zero. Such assumption is reasonable for very large particles, for which the extinction optical depth becomes dependent on particle size but not wavelength.

In order to describe both fine and coarse modes, a log-normal number particle size distribution $\mathrm{N}_{\mathrm{i}}$ is assumed with median radius $\mathrm{R}_{\mathrm{ni}}$ and width $\ln \left(\sigma_{\mathrm{i}}\right)$ :

$$
\frac{d N_{i}}{d \ln r}=\frac{N_{c i}}{\sqrt{2 \pi} \ln \left(\sigma_{i}\right)} \exp \left(-\frac{\ln \left(\frac{r}{R_{n i}}\right)^{2}}{2 \ln ^{2} \sigma_{i}}\right)
$$

(Equation 3)

where i $(=\mathrm{c}, \mathrm{f})$ stands for fine or coarse mode, and $\mathrm{N}_{\mathrm{ci}}$ is the number concentration. Data by O'Neill et al. (2001) yield $\mathrm{AE}_{\mathrm{AOD}}$ values about 0.1 or lower for a polydispersion of particles with median radii as low as $0.43 \mu \mathrm{m}(\sigma=2.2)$. Our computations under Mie theory, based on a lower value of the size distribution width as suggested by Hansen and Travis (1974), yield $\mathrm{AE}_{\mathrm{AOD}}<0.1$ for median radii larger than about $1.5 \mu \mathrm{m}$, thus allowing the nearly-zero Angström exponent approximation to be safely used on some coarse mode aerosol models, e.g. sea salt and coarse mineral as described by the OPAC database (Hess et al. 1998).

Following this concept, Gobbi et al. (2007) introduced a graphical framework based on the AOD at three particular wavelengths. A graphical plot of three Angström 
exponents is made in the two-dimensional form $\Delta \mathrm{AE}_{\mathrm{AOD}}=\mathrm{AE}_{\mathrm{AOD}}\left(\lambda_{1}, \lambda_{2}\right)-\mathrm{AE}_{\mathrm{AOD}}\left(\lambda_{2}, \lambda_{3}\right)$ vs. $\operatorname{AE}_{\mathrm{AOD}}\left(\lambda_{1}, \lambda_{3}\right)$. An average of four different coarse mode populations was assumed, each with a different value of the coarse mode radius $(0.75,1,2$, and $4 \mu \mathrm{m})$, and the same value for the coarse mode distribution width $\left(\sigma_{c}=1.8\right)$ and fixed fine-mode distribution width $\left(\sigma_{\mathrm{f}}=1.5\right)$. These parameters are representative of AERONET aerosol retrievals for various sites, source regions and particle compositions (Dubovik et al. 2002). Mie calculations for such coarse mode populations in the case of a refractive index $\mathrm{m}=1.4+\mathrm{i} 0.001$ yield a range of $\mathrm{AE}_{\mathrm{AOD}}$ Values from -0.05 to -0.21 at wavelengths 440-675, and 675-870 mn. The average $A E_{A O D}$ Values obtained for the coarse mode are $\mathrm{AE}_{\mathrm{AOD}, \mathrm{c}}=-0.1028$ and $\Delta \mathrm{AE}_{\mathrm{AOD}, \mathrm{c}}=0.03$. The assumption of nearly-zero $\mathrm{AE}_{\mathrm{AOD}}$ values for such parameters is therefore reasonable. As a consequence, each point in the so-called $\mathrm{AE}_{\mathrm{AOD}}-\triangle \mathrm{AE}_{\mathrm{AOD}}$ grid depends on two parameters, namely the fine-mode median radius $\left(R_{f}\right)$ and the contribution of the fine mode to the total AOD $(\eta)$. The Gobbi grid crisscrosses the AOD space representing the values with either $R_{f}$ constant or $\eta$ constant. Values typically chosen for grid representation are $\mathrm{R}_{\mathrm{f}}=0.05,0.1,0.15,0.2,0.3$, and $0.5 \mu \mathrm{m}$, and $\eta=1,10,30,50,70,90$ and $99 \%$.

Calculation of the Gobbi framework points can be a heavy and burdersome task, as they depend on several particle parameters such as shape and composition. In particular, nonsphericity demands the use of mathematical methods far more complicated and CPU-intensive that the usual Mie theory for spherical scatterers. The effect of nonsphericity is expected to have an impact on these results, and that impact should be quantified in order to assess whether spherical shape can be assumed. It is generally assumed that the effect of nonsphericity should be small since shape has little effect on extinction for large particle size (Mishchenko, 1997; Gobbi et al, 2007).

The sensitivity of the Gobbi/like grid plots based on $A E_{A O D}-\Delta E_{A O D}$ can be seen in Fig 1. Spheroidal particles have been modeled as a $50 \%$ mixture of oblate and prolate spheroids with the axial ratio (long to short axis ratio) $\mathrm{e}=1.8$ and equal-volume median radius, and the resulting extinction values have been calculated by using $\mathrm{T}$ matrix theory (Waterman, 1971). In order to ease the computational burden, a set of kernel functions was calculated and used (Quirantes et al., 2010) following a scheme similar to Dubovik et al. (2006). Particle size and composition parameters in this work are equal to those of Gobbi et al. (2007). 
Results show that the shape effect is negligible in most cases, and only becomes noticeable for high $R_{f}$ values $(>0.2 \mu \mathrm{m})$. The average coarse-mode value for $A E_{A O D}$ change from -0.103 to -0.130 , while $\Delta \mathrm{AE}_{\mathrm{AOD}}$ remains almost unchanged (0.0299 to 0.0293). The assumption by Gobbi et al. (2007) that aerosol shape should not be expected to significantly affect grid plot coordinates is thus confirmed. In view of this result, it can be safely assumed that the use of Mie theory for spherical particles in $A E_{A O D}-\triangle A E_{A O D}$ plots is adequate without having to resort to other, more complicated methods assuming nonspherical scatterers.

Regarding the well-known dependence of the grid on refractive index (Perrone et al., 2014), it must be pointed out that sensitivity studies typically assumes equal composition for fine and coarse modes, but natural mixtures of different modes can have different values of refractive index for fine and coarse modes (Eck et al., 2010; Valenzuela et al., 2014), and such differences between modes must be taken into account.

A set of comparisons using different values of the refractive index for both fine and coarse mode show that the $\mathrm{AE}_{\mathrm{AOD}}-\Delta \mathrm{AE}_{\mathrm{AOD}}$ grid point seems to be unaffected by changes in the refractive index of the coarse mode. An example is shown in Fig. 2 where the change in coarse mode composition has little effect on the grid points. It follows that only the refractive index of the fine mode is relevant in creating a Gobbi grid, whereas composition of the coarse mode exhibits a negligible impact. The retrieved fine median values $\mathrm{R}_{\mathrm{f}}$ is, therefore, dependent on the value of the refractive index chosen for the fine mode alone.

Classical $\mathrm{AE}_{\mathrm{AOD}}-\triangle \mathrm{AE}_{\mathrm{AOD}}$ Gobbi grids are known to show a clockwise rotation about the origin of the constant radius curves for increasing refractive index. For a given point, Gobbi et al., (2007) shows that maximum $R_{f}$ indetermination ranges about $\pm 25 \%$ when the index of refraction varies from 1.33 to $1.53+\mathrm{i} 0.003$, whereas $\eta$ spans a range of about $\pm 10 \%$; similar values for other index of refraction and wavelengths values are found in Perrone et al., (2014)

It must be pointed out, however, thar the index of refraction is a complex number (the imaginary part describing the effect of attenuation), so the term "increasing” is a bit confusing. Our tests confirm that a clockwise rotation is obtained for both increasing real part (with constant imaginary part) and increasing imaginary part (with constant real part) of the refractive index. 
It is worth mentioning that the graphical classification of Gobbi et al (2007) can be seen as a manifestation of deeper, fundamental analytical relations in the space formed by the Angstrom exponent and its spectral derivative, which are in turn obtained by means of a spectral deconvolution algorithm (SDA), as O'Neill (2010) pointed out.

\subsection{Vertical resolved data}

The multiwavelength Raman lidar MULHACÉN was used to retrieve verticallyresolved particle extinction and backscatter coefficients at 355, 532 and $1064 \mathrm{~nm}$. Particle extinction and backscatter coefficients at 355 and $532 \mathrm{~nm}$ were independently retrieved by the Raman method (Ansmann et al. 1992), with an uncertainty of 5\% and $10 \%$ for extinction and backscatter, respectively. Particle backscatter coefficients at $1064 \mathrm{~nm}$ were retrieved by the Klett-Fernald method (Klett 1985) using a particle lidar ratio of $50 \mathrm{sr}$. The corresponding particle extinction coefficient at $1064 \mathrm{~nm}$ was obtained multiplying the particle backscatter profile by the particle lidar ratio. The uncertainties for backscatter and extinction profiles obtained by Klett-Fernald method are usually $20 \%$ and $25-30 \%$, respectively.

\subsection{Backscatter grid plot}

Computation of aerosol backscattered profiles can be obtained by backscattering lidar using assumptions about the extinction-to-backscattered ratio - typically known as lidar ratio (LR). The use of Raman or HSRL system, however, allows a direct computation of backscattering coefficients without the need of LR assumptions. Multiwavelength backscattering coefficients can be used for determination of particle mass concentration and size distribution (Gasteiger et al., 2011). Combined with polarization lidar, multiwavelengthlidars allow for the separation of spherical and nonspherical particles as a function of height (Shimizu et al., 2004; Quirantes et al., 2012; Burton et al., 2014; Bravo-Aranda et al., 2015).

An $\mathrm{AE}_{\beta}-\Delta \mathrm{AE}_{\beta}$ plot might be an additional tool to infer particle properties from the measured backscattered lidar signals. Layer-by-layer analysis is particularly helpful, in a way similar to that used by Perrone et al. (2014) for particle extinction profiles. This procedure is, unfortunately, unworkable in practical terms. $A n A_{\beta}-\Delta \mathrm{AE}_{\beta}$ grid is heavily dependent on particle composition (Fig. 3) and particle shape (Fig. 4), due to the 
fact that the particle backscatter coefficient is highly sensitive to particle shape and refractive index (Ansmann et al., 2003).

In addition, plot lines do not always rotate in a clockwise direction for increasing values of the fine mode radius $R_{\mathrm{f}}$. Instead, rotation is first counterclockwise then clockwise. As a consequence, there is no unique correspondence between a $\mathrm{R}_{\mathrm{f}}$ value and a particular location in $\mathrm{AE}_{\beta}-\Delta \mathrm{AE}_{\beta}$ space. Even with an exact knowledge of particle size, shape, and composition, the use of $\mathrm{AE}_{\beta}-\Delta \mathrm{AE}_{\beta}$ seems unsuitable for practical applications.

\section{RESULTS AND DISCUSSION}

\subsection{Classification for particle concentration}

As seen before, one of the variables for the $A E_{A O D}-\triangle A E_{A O D}$ grid is the fine mode contribution to total AOD ( $\eta$ ). This raises the point, would it be possible to plot data on a grid where the fine mode contribution is not measured as $\eta$, but as the fine mode contribution to the full aerosol population, i.e. $F_{n}=N_{c f} /\left(N_{c f}+N_{c c}\right.$ ) (where $N_{c f}$ is the number concentration of particles in fine-mode and $\mathrm{N}_{\mathrm{cc}}$ is the number concentration of particles in coarse-mode)? If so, a change in relative concentration of both modes could be followed as a $F_{n}$-constant curve, and it could be separated from other causes like particle growth.

While theoretically feasible, any such attempt encounters several difficulties, the first being that such $A E_{A O D}-\triangle A_{A O D}$ grid includes very high values of $F_{n}$. As Fig. 5 shows, most of the grid space is occupied by particle concentrations with large values of fine mode concentration, and the range values for extinction Angström coefficients have shrunk. As a consequence, small variations to values will translate into large changes in $F_{n}$.

To overcome this drawback, a particle-concentration-based $A E_{A O D}-\triangle A_{A O D}$ grid is here proposed that is similar to the original Gobbi plot, with the main difference being that a different size distribution is considered. A bimodal log-normal distribution is still used, but is volume-based $\left(\mathrm{V}_{\mathrm{i}}\right)$ instead of number-based $\left(\mathrm{N}_{\mathrm{i}}\right)$ : 


$$
\frac{d V_{i}}{d \ln r}=\frac{C_{v i}}{\sqrt{2 \pi} \ln \left(\sigma_{i}\right)} \exp \left(-\frac{\ln \left(\frac{r}{R_{v i}}\right)^{2}}{2 \ln ^{2} \sigma_{i}}\right)
$$

where the median radius and normalization constant for both distributions are related as:

$$
\begin{gathered}
R_{v i}=R_{n i} \exp \left(-3 \ln ^{2} \sigma_{i}\right) \\
C_{c v}=\frac{4}{3} \pi r_{n}^{3} N_{c i} \exp \left(4.5 \ln ^{2} \sigma_{i}\right)
\end{gathered}
$$

Now the fine-mode number ratio $\mathrm{F}_{\mathrm{n}}=\mathrm{N}_{\mathrm{cf}} /\left(\mathrm{N}_{\mathrm{cf}}+\mathrm{N}_{\mathrm{cc}}\right)$ can be substituted by the finemode volume ratio $\mathrm{F}_{\mathrm{v}}=\mathrm{C}_{\mathrm{vf}} /\left(\mathrm{C}_{\mathrm{vf}}+\mathrm{C}_{\mathrm{vc}}\right)$. As an example, calculations for a bimodal particle size distribution with parameters as given in Table 1 yield a number ratio of $F_{n}=99.9947 \%$ and a volume ratio $F_{v}=16.2 \%$. In this way, it can be seen that number ratio values close to $100 \%$ can correspond to low volume ratio values.

Fig. 6 shows the Gobbi diagram, modified so that dotted lines represent constant values of the volume fraction $F_{v}$. Experimental data can be plotted and immediate information can be retrieved regarding the relative presence of the fine mode. As Equation 2 shows, the Angström exponent for the full bimodal distribution ( $\left.\mathrm{AE}_{\mathrm{AOD}}\right)$ can be related to those for the separate fine $\left(A E_{A O D, f}\right)$ and coarse $\left(A E_{A O D, c}\right)$ modes by means of $\eta$ (the AOD contribution of the fine mode to total extinction). If two coarse mode size radii $\mathrm{R}_{\mathrm{c} 1}, \mathrm{R}_{\mathrm{c} 2}$ are considered, two $A E_{\mathrm{AOD}}$ values $(\mathrm{i}=1,2)$ can be calculated:

$$
A E_{A O D, i}=A E_{A O D, f i} \cdot \eta_{i}+A E_{A O D, c i} \cdot\left[1-\eta_{i}\right]
$$

when the coarse mode size radii $\mathrm{R}_{\mathrm{c} 1}, \mathrm{R}_{\mathrm{c} 2}$ are chosen so that their contributions to the Angström exponent are similar $\left(\mathrm{AE}_{\mathrm{AOD}, \mathrm{f} 1} \approx \mathrm{AE}_{\mathrm{AOD}, \mathrm{f} 2}\right)$, then equal $\eta$ values yield equal $\mathrm{AE}_{\mathrm{AOD}, \mathrm{i}}$ values, and are therefore represented as equal points on the classical $\mathrm{AE}_{\mathrm{AOD}}-$ $\Delta \mathrm{AE}_{\mathrm{AOD}}$ grid. The Angström exponent for a coarse mode $\left(\mathrm{AE}_{\mathrm{AOD}, \mathrm{c}}\right)$ can be then assumed to be equal to the average of the two (or four, as in the case of the classical Gobbi diagram).

This cannot be exported to a grid where one of the main parameters has changed from $\eta$ to $F_{v}$. Equal $F_{v}$ values does not necessarily mean equal $\eta$ values, and therefore will not be translated as equivalent points on the $\mathrm{AE}_{\mathrm{AOD}}-\triangle \mathrm{AE}_{\mathrm{AOD}}$ grid as even slight variations can translate to large difference in the $\mathrm{AE}_{\mathrm{AOD}}-\triangle \mathrm{AE}_{\mathrm{AOD}}$ grid points. As an 
example, Table 2 shows the values of the $A E_{A O D}-\Delta A E_{A O D}$ grid point for $R_{f}=0.05 \mu m$, $\mathrm{Fv}=30 \%$, and three different values for the coarse radius. Still, a direct representation of volume fraction could be useful for particular purposes. Fig 7 shows $A E_{A O D}-\triangle A E_{A O D}$ grid plot details for a refractive index $\mathrm{m}=1.44+\mathrm{i} 0.0097$ and a coarse mode volume particle distribution $\left(\mathrm{R}_{\mathrm{c}}=3.23 \mu \mathrm{m}, \sigma_{\mathrm{c}}=2.2\right)$. These parameters are representative of aerosol populations by transported mineral aerosol as given by OPAC (Hess et al. 1998). Since our data indicates that the $A E_{A O D}-\triangle A E_{A O D}$ diagram is more influenced by the refractive index of the fine mode, the value $\mathrm{m}=1.44+\mathrm{i} 0.0097$ has been chosen as suggested by Dubovik et al., (2002) for urban/industrial environments. Fine mode has been set in both cases as $\sigma_{\mathrm{f}}=1.5$.

Numerical values for the plots in Figs. 6 and 7, for wavelength values 440, 675, 870, are given in Tables 3 and 4, respectively. The sensitivity of these modified Gobbi plots have been tested by comparing results for $m=1.33$ and $m=1.52+i 0.0028$. For a given point, $\mathrm{R}_{\mathrm{f}}$ indetermination has been found to be similar to those reported by Gobbi et al., (2007) and Perrone et al (2014). The substitution of the variable $\eta$ by Cv does not seem to alter its indetermination range either.

Additionally, plot data values are given in Table 5 for wavelengths 355, 532, $1064 \mathrm{~nm}$, which have a wide range of applications in lidar measurements and will be used in the next section.

\subsection{Application to an experimental case with lidar measurements}

Data gathered during ChArMEx-ADRIMED (Mallet et al., 2016) campaign at Granada on 16 and 17 June 2013 gives us an excellent opportunity to evaluate algorithms for retrieving aerosol microphysical and optical profiles (Benavent-Oltra et al., 2017) and in turn, these properties and data were used as inputs of the radiative transfer model Global Atmospheric ModEl (Granados-Muñoz et al., 2019). On these days, Saharan mineral dust particles with origin in southern Morocco (near the border with Algeria) where advected over Granada after a travel of around 4 days, according to back-trajectories analysis (Benavent-Oltra et al., 2017). A homogenous mineral dust layer was monitored at up to $5 \mathrm{~km}$ a.g.l. on June 16, whereas on June 17 the dust layer was decoupled from the atmospheric boundary layer and mainly located between 2 and $4.5 \mathrm{~km}$ a.g.l. The focus here is on the period from 20:30 UTC on 16 June to 01:30 UTC 
on 17 June where 30-min optical lidar profiles where successfully retrieved, covering layers in the height range 1600-5800 m for six 30-minute intervals.

Particle size distribution data provided by AERONET (June 16, 16:53h UTC can be fitted to a bimodal volume size distribution with median radii and width $(0.12 \mu \mathrm{m}$, $\sigma=1.78)$ for the fine mode and $(1.85 \mu \mathrm{m}, \sigma=1.89)$ for the coarse mode. The columnintegrated volume fraction for fine mode is estimated from AERONET data as $10 \%$ for June 16, 16:53h UTC and 12\% for June 17, 07:41h UTC.

Figures 9 a,b show plotted values for column-integrated Angström exponent values at different times, in two $\mathrm{AE}_{\mathrm{AOD}}-\triangle \mathrm{AE}_{\mathrm{AOD}}$ plots: constant $\mathrm{AOD}$ fraction (9a), and constant volume fraction (9b). In all but two of the six values, fine-mode fraction fell within the AERONET-retrieved data (10 - $12 \%)$. Fine mode particle sizes values range between 0.2 and $0.4 \mu \mathrm{m}$, somewhat larger than the AERONET-derived value $(0.12 \mu \mathrm{m})$. The reason for the discrepancy is not well known, but as both plots yield similar finemode particle sizes, it seems to be a common feature with Gobbi-like plot grid schemes.

Regarding the characterization of volume fraction $F_{v}$ values obtained from Figure $8 \mathrm{~b}(6-15 \%)$ compare well to the AERONET-determined value of $8-11 \%$. A comparison of Figures 8a and 8b show that the presence of such fraction range of coarse particles contribute to $40-60 \%$ of the total (column-integrated) extinction.

\subsection{Application to synthetic data (GEOS-5)}

Synthetic data from the Goddard Earth Observing System, version 5 (GEOS-5, Rienecker et al., 2011; Moled et al., 2012) are used. GEOS-5 includes modules representing the atmospheric composition and tropospheric/stratospheric constituents (Pawson et al., 2008). For aerosol particles, the GEOS-5 uses the GOCART module (Chin et al., 2002) to simulate the emissions, transport, and deposition of dust, sea salt, carbonaceous and sulfate particle. Dust and sea salt particle size distributions are resolved over five size bins (Colarco et al., 2014). Carbonaceous aerosols are resolved into black and organic carbon, partitioned by hydrophobic and hydrophilic fractions.

GEOS-5 is highly configurable, supporting various spatial resolutions, and in this work the so-called "nature run” was used (https://gmao.gsfc.nasa.gov/global_mesoscale/7km-G5NR/), which is a two-year (June 2005 - June 2007) global 7-km horizontal resolution simulation of the atmosphere 
including forced aerosols. The nature run was performed as a climate simulation, forced only by observed sea surface temperatures and with a relaxation of the model convective parameterization as the non-hydrostatic dynamical core resolved more of the relevant scales of motion. The model run had 72 vertical levels from the surface to 0.01 $\mathrm{hPa}$ and was run with a 5 minutes physics time step. For the data used here, the GEOS-5 model was used to simulate the atmospheric conditions along $24 \mathrm{~h}$ track of the CALIOP lidar instrument valid for $24^{\text {th }}$ July 2009 , representative of many aerosol conditions for the evaluation of aerosol retrievals (e.g. Whiteman et al., 2018). The GEOS-5 simulation was run using assimilated meteorology from its own Modern-Era Retrospective Analysis for Research and Applications (MERRA - Rienecker et al., 2011). GEOS-5 data used here include vertical profiles of particle backscatter and extinction coefficients at 355, 532 and $1064 \mathrm{~nm}$, including also the contribution of each aerosol specie.

Figure 9 shows an example of aerosol profiling for a study case over Northeast Africa, near the Senegal coast. Backscattering and extinction profiles and also the fraction of each species to aerosol extinction are shown. A clear predominance of dust is observed, although influence of sulphate $(\approx 20 \%)$ and organic carbon $(\approx 10 \%)$ particles is seen at high altitudes (above $4 \mathrm{~km}$ ), probably due to transport of biomass particles from southern latitudes. Such aerosol situations have been observed in the real atmosphere from real lidar measurements (e.g. Veselovskii et al., 2018). Effective radius (graph not shown for clarity) takes values between 1 and $1.5 \mu \mathrm{m}$, which indicate large predominance of coarse mode. Also, 95\% in volume is found in the first $7 \mathrm{~km}$. Classical Gobbi plots (Fig. 10a) reproduces the profile pattern well, revealing a dust contribution to total extinction of $70 \%$ at the lowest level (625 $\mathrm{m}$ a.s.l.), decreasing to about $40 \%$ at $7 \mathrm{~km}$. Volume fraction plots (Fig. 10b) show a relative volume values for dust fraction close ranging from 95\% (at $625 \mathrm{~m}$ above ground level) to 85-90\% (at $7 \mathrm{~km}$ a.g.l.). At heights above $8 \mathrm{~km}$, contributions come mostly from fine mode particles (sulphate/carbon species) with 25-35\% volume fraction, which agree with the percentages of sulphate/carbon particles of 20-30\% showed in Figure 9c. Volume median radius differs slightly $(0.2 \mu \mathrm{m}$ according to volume plot, 0.31 according to OPAC data). The presence of additional small-size particle populations at heights above $8 \mathrm{~km}$ (mainly organic and black carbon, with a combined volume fraction of up to 15\%, and a volume median ratio $0.05 \mu \mathrm{m}$ ) might be a factor to account for the discrepancy. 
Figure 11 shows an example of backscattering and extinction aerosol properties for an example of aerosol pollution over East Asia. Fractions of each species to aerosol extinction are also shown. Most aerosol contribution occurs within the planetary boundary layer at approximately $2200 \mathrm{~m}$ a.s.l. In this layer, sulphate is by far the predominant aerosol specie, but other aerosol layers are encountered in the free troposphere: Above PBL GEOS-5 simulations reveal some remaining particles within 5-7 km, mostly associated to carbonaceous (organic and black carbon). Eventually, another aerosol layer is found between $8-10 \mathrm{~km}$ where again largely sulphate particles as found for the PBL predominate. The aerosol layers in the free troposphere would be very difficult to detect and analyze from real measurements because of very low loads. However, GEOS-5 allows for is characterization. Such layers might are not real but in any case they are realistic situations that can happen in the real atmosphere.

Gobbi/like plots for the data of Figure 11 are shown in Figure 12a. Large pollution particles spread mainly in the lower/medium (0.7-5.5 km) and upper (8-10 $\mathrm{km})$ levels, while intermediate level $(5-8 \mathrm{~km})$ is populated by a mixture of organic and black carbon particles. Volume plot (Fig. 12b) for both lower and upper levels suggest a fine-particle population of about $0.3 \mu \mathrm{m}$ volume median radius and 30-50\% volume fraction, which agrees with simulated data $(0.31 \mu \mathrm{m}, 20-40 \%)$. In the intermediate levels, the two-population hypothesis no longer holds, and three different populations are present representing dust, organic carbon and black carbon. Still, Figure 12b shows a shift towards fine-particle populations of smaller radii $(0.17 \mu \mathrm{m}, 40 \%$ fine particle volume) in the 5-8 $\mathrm{km}$ height range. Due to the effect of clockwise rotation for increasing refractive index, a tailored volume fraction grid for black/organic carbon would yield smaller particle radii, closer to the OPAC value of about $0.05 \mu \mathrm{m}$, which is consistent with the radius values for black carbon given in GOCART/OPAC (Chin et al., 2002).

As conclusion, the modified Gobbi/like plots presented here have been demonstrated to distinguish different aerosol layer with different contributions of fine/coarse volumes. We remark that our analyses from GEOS-5 are realistic for different aerosol conditions presented in the atmosphere. However, GEOS-5 do not include internal mixtures for aerosol, and therefore many real cases are not included in our analyses. 


\section{CONCLUSIONS}

A modification of the classical Gobbi plot diagrams has been proposed to obtain quantitative information on the atmospheric aerosol content using direct-sun photometric observations at three wavelengths. This new plot yields fine-mode volume fraction directly, instead of being based on the relative AOD contribution.

Grid curves yield the contribution of small particles to the full, two-population size distribution, in contrast to former plots where only the contribution to light extinction was obtained. The new grid plot works on the condition that a bimodal, volume-based size distribution is used. Additionally, Gobbi grid plots based on lidar backscatter measurements have been tried and ruled out, showing that they are too sensitive to shape and composition to be useful by itself for particle characterization. However, as a potential application in the future, our Gobbi grids plots can be easily applied to perform a quality check on the particle backscatter retrievals in addition to quality checks based only on the coherence in terms of backscatter-related Angström exponent values.

\section{ACKNOWLEDGEMENTS}

This work was supported by the Andalusia Regional Government through project P12-RNM-2409 and the Spanish Ministry of Sciences, Innovation and Universities (CGL2016-81092 and CGL2017 -90884 - REDT). The financial support for EARLINET in the ACTRIS Research Infrastructure Project by the European Union's Horizon 2020 research and innovation program under grant agreement $\mathrm{n}$. 654169 is gratefully acknowledged. The authors thankfully acknowledge the FEDER program for the instrumentation used in this work. This work was also partially funded by the University of Granada through the contract "Plan Propio. Programa9. Convocatoria 2013" and the project UCE-PP2017. The authors express gratitude to the NOAA Air Resources Laboratory (ARL) for the HYSPLIT transport and dispersion model. Part of this work was supported by University of Granada and EU H2020 throught the MCS-COFUND Athenea3i. 



\section{REFERENCES}

Angström, A., 1929. On the atmospheric transmission of sun radiation and on dust in the air. Geogr. Ann. 11, 156-166. https://doi.org/10.2307/519399.

Ansmann, A., Wandinger, U., Riebesell, M., Weitkamp, C., Michaelis, W., 1992. Independent measurement of extinction and backscatter profiles in cirrus clouds by using a combined Raman elastic-backscatter lidar. Appl. Opt. 31, 7113-7131. https://doi.org/10.1364/AO.31.007113.

Ansmann, A., Bösenberg, J., Chaikovsky, A., Comerón, A., Echkardt, S., Eixmann, R., Freudenthaler, V., Ginoux, P., Komguem, L., Linné, H., LópezMárquez, M.A., Matthias, V., Mattis, I., Mitev, V., Müller, D., Music, S., Nickovic, S., Pelon, J., Sauvage, L., Sobolewsky, P., Srivastava, M.K., Stohn, A., Torres, O., Vaughan, G., Wandinger, U., Wiegner, M., 2003. Long-range transport of Saharan dust to northern Europe: the 11-16 October 2001 outbreak observed with EARLINET, J. Geophys. Res. 108 (D24). https://doi.org/10.1029/2003JD003757.

Bedoya-Velásquez, A.E., Navas-Guzmán, F., de Arruda Moreira, G., Román, R., Cazorla, A., Ortiz-Amezcua, P., Benavent-Oltra, J.A., Alados-Arboledas, L., OlmoReyes, F.J., Foyo-Moreno, I., Montilla-Rosero, E., Hoyos, C.D., Guerrero-Rascado, J.L., 2019. Seasonal analysis of the atmosphere during five years by using microwave radiometry over a mid-latitude site, Atmos. Res., 218, 78-89.

Benavent-Oltra, J. A., Román, R., Granados-Muñoz, M. J., Pérez-Ramírez, D., OrtizAmezcua, P., Denjean, C., Lopatin, A., Lyamani, H., Torres, B., Guerrero-Rascado, J. L., Fuertes, D., Dubovik, O., Chaikovsky, A., Olmo, F. J., Mallet, M., AladosArboledas, L., 2017. Comparative assessment of GRASP algorithm for a dust event over Granada (Spain) during ChArMEx-ADRIMED 2013 campaign. Atmos. Meas. Tech. 10, 4439-4457, https://doi.org/10.5194/amt-10-4439-2017. 
Bravo-Aranda, J.A., Titos, G., Granados-Muñoz, M.J., Guerrero-Rascado J.L., NavasGuzmán F., Valenzuela A., Lyamani H., Olmo F.J., Andrey J., Alados-Arboledas L., 2015. Study of mineral dust entrainment in the planetary boundary layer by lidar depolarisation technique. Tellus B 26180, http://dx.doi.org/10.3402/tellusb.v67.26180.

Burton, S.P., Vaughan, M.A., Ferrare, R.A., Hostetler, C.A., 2014. Separating mixtures of aerosol types in airborne High Spectral Resolution Lidar data. Atmos. Meas. Tech. 7, 419-436. https://doi.org/10.5194/amt-7-419-2014.

Burton, S.P., Chemyakin, E., Liu, X., Knobelspiesse, K., Stamnes, S., Sawamura, P., Moore, R.H., Hostetler, C.A., Ferrare, R.A., 2016. Information content and sensitivity of the $3 \beta+2 \alpha$ lidar measurement system for aerosol microphysical retrievals.Atmos. Meas. Tech. 9, 5555-5574. https://doi.org/10.5194/amt-9-5555-2016.

Cazorla, A., Casquero-Vera, J. A., Román, R., Guerrero-Rascado, J. L., Toledano, C., Cachorro, V. E., Orza, J. A. G., Cancillo, M. L., Serrano, A., Titos, G., Pandolfi, M., Alastuey, A., Hanrieder, N., Alados-Arboledas, L., 2017. Near-real-time processing of a ceilometer network assisted with sun-photometer data: mon itoring a dust outbreak over the Iberian Peninsula. Atmos. Chem. Phys., 17, 11861-11876, https://doi.org/10.5194/acp-17-11861-2017.

Chaikovsky, A., Dubovik, O., Goloub, P., Tanré, D., Pappalardo, G., Wandinger, U., Chaikovskaya, L., Denisov, S., Grudo, Y., Lopatsin, A., Karol, Y., Lapyonok, T., Korol, M., Osipenko, F., Savitski, D., Slesar, A., Apituley, A., Arboledas, L. A., Binietoglou, I., Kokkalis, P., Granados-Muñoz, M. J., Papayannis, A., Perrone, M. R., Pietruczuk, A., Pisani, G., Rocadenbosch, F., Sicard, M., De Tomasi, F., Wagner, J., Wang, X., 2012. Algorithm and software for the retrieval of vertical aerosol properties using combined lidar/radiometer data: dissemination in EARLINET, in: Proceedings of the 26th International Laser and Radar Conference, Porto Heli, Greece, 25-29 June 2012, 399-402. http://hdl.handle.net/2117/86295.

Chaikovsky, A., Dubovik, O., Holben, B., Bril, A., Goloub, P., Tanré, D., Pappalardo, 
G., Wandinger, U., Chaikovskaya, L., Denisov, S., Grudo, J., Lopatin, A., Karol, Y., Lapyonok, T., Amiridis, V., Ansmann, A., Apituley, A., Allados-Arboledas, L., Binietoglou, I., Boselli, A., D'Amico, G., Freudenthaler, V., Giles, D., GranadosMuñoz, M. J., Kokkalis, P., Nicolae, D., Oshchepkov, S., Papayannis, A., Perrone, M. R., Pietruczuk, A., Rocadenbosch, F., Sicard, M., Slutsker, I., Talianu, C., de Tomasi, F., Tsekeri, A., Wagner, J., Wang, X., 2016. Lidar-Radiometer Inversion Code (LIRIC) for the retrieval of vertical aerosol properties from combined lidar/radiometer data: development and distribution in EARLINET. Atmos. Meas. Tech. 9, 1181-1205, https:// doi.org/10.5194/amt-9-1181-2016, 2016.

Chin, M., Ginoux, P., Kinne, S., Torres, O., Holben, B.N., Duncan, B.N., Martin, R.V., Logan, J.A., Higurashi, A., Nakajima, T., 2002. Tropospheric Aerosol Optical Thickness from the GOCART Model and Comparisons with Satellite and Sun Photometer Measurements. J. Atmos. Sci. 59, 461-483. https://doi.org/10.1175/15200469(2002)059<0461:TAOTFT>2.0.CO;2.

Colarco, P., Nowottnick, E.P., Randles, C.A., Yi, B., Yang, P., Kim, K-M, Smith, J.A., Bardeen, G., 2014. Impact of radiatively interactive dust aerosols in the NASA GEOS-5 climate model: Sensitivity to dust particle shape and refractive index. J. Geophys. Res. Atmospheres 119, 753-786. https://doi.org/10.1002/2013JD020046.

Córdoba-Jabonero, C., Sorribas, M., Guerrero-Rascado, J. L., Adame, J. A., Hernández, Y., Lyamani, H., Cachorro, V., Gil, M., Alados-Arboledas, L., Cuevas, E., de la Morena, B., 2011. Synergetic monitoring of Saharan dust plumes and potential impact on surface: a case study of dust transport from Canary Islands to Iberian Peninsula. Atmos. Chem. Phys. 11, 3067-3091, https://doi.org/10.5194/acp-11-3067-2011.

Dubovik, O., King, M.D., 2000. A flexible inversion algorithm for retrieval of aerosol optical properties from Sun and sky radiance measurements. J. Geophys. Res. 105, 20673-20696. https://doi.org/10.1029/2000JD900282.

Dubovik, O., Holben, B. N., Eck, T. F., Smirnov, A., Kaufman, Y. J., King, M. D., Tanre D., Slutsker I., 2002. Varibility of absorption and optical properties of key 
aerosol types observed in worldwide locations. J. Atmos. Sci. 59, 590-608. https://doi.org/10.1175/1520-0469(2002)059<0590:VOAAOP>2.0.CO;2.

Dubovik, O., Sinyuk, A., Lapyonok, T., Holben, B. N., Mishchenko, M., Yang, P., Eck, T. F., Volten, H., Muñoz, O., Veihelmann, B., van der Wande, W. J., Leon, J-F., Sorokin, M., Sluskher, I., 2006. Application of spheroid models to account for aerosol particle nonsphericity in remote sensing of desert dust. J. Geophys. Res. 111, D11208. https://doi.org/10.1029/2005JD006619.

Dubovik, O., Herman, M., Holdak, A., Lapyonok, T., Tanre, D., Deuze, J. L., Ducos, F., Sinyuk, A., Lopatin, A., 2011.: Statistically-optimized inversion algorithm for enhanced retrieval of aerosol properties from spectral multi-angle polarimetric satellite observations. Atmos. Meas. Tech. 4, 975-1018, https://doi.org/10.5194/amt-4-975$\underline{2011 .}$

Dubovik, O., Lapyonok, T., Litvininov, P., Herman, M., Fuertes, D., Ducos, F., Lopatin, A., Chaikovsky, A., Torres, B., Derimian, Y., Huang, X., Aspetsberger, M., Federspiel, C., 2014. GRASP: a versatile algorithm for characterizing the atmosphere, SPIE Newsroom. https://doi.org/10.1117/2.1201408.005558.

Eck, T. F., Holben, B. N., Sinyu, A., Pinker, R. T., Goloub, P. Chen, H., Chatenet, B., Li, Z., Singh, R. P., Tripathi, S. N., Reid, J. S., Giles, D. M., Dubovik, O., O'Neill, N. T., Smirnov, A., Wang, P., Xia, X.:, 2010. Climatological aspects of the optical properties of fine/coarse mode aerosol mixtures. J. Geophys. Res. 115, D19205. https:// doi.org/doi:10.1029/2010JD014002.

Gasteiger, J., Gross, S., Freudenthaler, V., Wiegner, M., 2011. Volcanic ash from Iceland over Munich: mass concentration retrieved from ground-based remote sensing measurements. Atmos. Chem Phys. 11, 2209-2223. https://doi.org/10.5194/acp-112209-2011. 
Gobbi, G. P., Kaufman, Y. J., Koren, I., Eck, T. F., 2007. Classification of aerosol properties derived from AERONET direct sun data. Atmos. Chem. Phys. 7, 453-458. https://doi.org/10.5194/acp-7-453-2007.

Granados-Muñoz, M. J., Sicard, M., Román, R., Benavent-Oltra, J. A., Barragán, R., Brogniez, G., Denjean, C., Mallet, M., Formenti, P., Torres, B., Alados-Arboledas, L., 2019. Impact of mineral dust on shortwave and longwave radiation: evaluation of different vertically-resolved parameterizations in 1-D radiative transfer computations. Atmos. Chem. Phys., 19, 523-542, https://doi.org/10.5194/acp-19-523-2019.

Guerrero-Rascado, J. L., Ruiz, B., Alados-Arboledas, L., 2008. Multispectral Lidar characterization of the vertical structure of Saharan dust aerosol over southern Spain. Atmos. Environ. 42, 2668-2681. https://doi.org/10.1029/2012JD018056

Guerrero-Rascado, J. L., Costa, M. J., Bortoli, D., Silva, D., Lyamani, H., AladosArboledas, L., 2010. Infrared lidar overlap function: An experimental determination. Opt. Express 18, 20350-20359. https://doi.org/10.1364/OE.18.020350.

Guerrero-Rascado, J. L., Müller, D., Navas-Guzmán, F., PérezRamirez, D., AladosArboledas, L., 2011. First results of aerosol microphysical properties by $3+2$ Raman lidar at EARLINET Granada station. Rom. J. Phys. 56, 467-475.

Guerrero-Rascado, J.L., Da Costa, R.F., Bedoya, A.E., Guardani, R., Alados-Arboledas, L., Bastidas, Á.E., Landulfo, E., 2014. Multispectral elastic scanning lidar for industrial flare research: Characterizing the electronic subsystem and application, Optics Express, 22 (25), 31063-31077.

Guerrero-Rascado, J.L., Landulfo, E., Antuña, J.C., de Melo Jorge Barbosa, H., Barja, B., Bastidas, Á.E., Bedoya, A.E., da Costa, R.F., Estevan, R., Forno, R., Gouveia, D.A., Jiménez, C., Larroza, E.G., da Silva Lopes, F.J., Montilla-Rosero, E., de Arruda Moreira, G., Nakaema, W.M., Nisperuza, D., Alegria, D., Múnera, M., Otero, L., Papandrea, S., Pallota, J.V., Pawelko, E., Quel, E.J., Ristori, P., Rodrigues, P.F., Salvador, J., Sánchez, M.F., Silva, A., 2016. Latin American Lidar Network 
(LALINET) for aerosol research: Diagnosis on network instrumentation, Journal of Atmospheric and Solar-Terrestrial Physics, 138-139, 112-120.

Hansen, J. E., Travis, L. D., 1974. Light scattering in planetary atmospheres. Space Sci. Rev. 16, 527-610. https://doi.org/10.1007/BF00168069.

Herman, B.M., Browning, S.R., Reagan, J.A., 1971. Determination of aerosol size distributions from lidar measurements. J. Atmos. Sci. 28, 763-771. https://doi.org/10.1175/1520-0469(1971)028<0763:DOASDF>2.0.CO;2.

Hess, M., Koepke, P., Schult, I., 1998. Optical properties of aerosols and clouds: the software package OPAC. B. Am. Meteorol. Soc. 79, 831-844. https://doi.org/10.1175/1520-0477(1998)079<0831:OPOAAC>2.0.CO;2.

Holben, B. N., Eck, T. F., Slutsker, I., Tanre, D., Buis, J. P., Setzer, A., Vermote, E., Reagan, J. A., Kaufman, Y.J., Nakajima, T., Lavenu, F., Jankowiak, I., Smirnov, A., 1998. AERONET - A federate instrument network and data archive for aerosol characterization. Remote Sens. Environ. 66, 1-16. https://doi.org/10.1016/S00344257\%2898\%2900031-5.

Kaufman, Y. J., 1993. Aerosol optical thickness and atmospheric path radiance. J. Geophys. Res. 98 (D2), 2677-2692. https://doi.org/10.1029/92JD02427.

Klett, J. D., 1985. Lidar inversion with variable backscatter/extinction ratios. Appl. Opt. 24(11), 1638-1643. https://doi.org/10.1364/AO.24.001638.

Lopatin, A., Dubovik, O., Chaikovsky, A., Goloub, P., Lapyonok, T., Tanré, D., Litvinov, P., 2013. Enhancement of aerosol characterization using synergy of lidar and sun-photometer coincident observations: The GARRLiC algorithm. Atmos. Meas. Tech. 6, 2253-2325. https://doi.org/10.5194/amt-6-2065-2013. 
Lyamani, H., Olmo, F. J., Alcántara, A., Alados-Arboledas, L., 2006a. Atmospheric aerosols during the 2003 heat wave in southeastern Spain I: Spectral optical depth. Atmos. Environ. 40, 6453-6464. https://doi.org/10.1016/j.atmosenv.2006.04.048.

Lyamani, H., Olmo, F. J., Alcántara, A., Alados-Arboledas, L., 2006b: Atmospheric aerosols during the 2003 heat wave in southeastern Spain II: microphysical columnar properties and radiative forcing. Atmos. Environ. 40, 6465-6476. https://doi.org/10.1016/j.atmosenv.2006.04.047.

Mallet, M., Dulac, F., Formenti, P., Nabat, P., Sciare, J., Roberts, G., Pelon, J., Ancellet, G., Tanré, D., Parol, F., Denjean, C., Brogniez, G., di Sarra, A., AladosArboledas, L., Arndt, J., Auriol, F., Blarel, L., Bourrianne, T., Chazette, P., Chevaillier, S., Claeys, M., D’Anna, B., Derimian, Y., Desboeufs, K., Di Iorio, T., Doussin, J.-F., Durand, P., Féron, A., Freney, E., Gaimoz, C., Goloub, P., Gómez-Amo, J. L., Granados-Muñoz, M. J., Grand, N., Hamonou, E., Jankowiak, I., Jeannot, M., Léon, J.F., Maillé, M., Mailler, S., Meloni, D., Menut, L., Momboisse, G., Nicolas, J., Podvin, T., Pont, V., Rea, G., Renard, J.-B., Roblou, L., Schepanski, K., Schwarzenboeck, A., Sellegri, K., Sicard, M., Solmon, F., Somot, S., Torres, B., Totems, J., Triquet, S., Verdier, N., Verwaerde, C., Waquet, F., Wenger, J., Zapf, P., 2016. Overview of the Chemistry-Aerosol Mediterranean Experiment/Aerosol Direct Radiative Forcing on the Mediterranean Climate (ChArMEx/ADRIMED) summer 2013 campaign. Atmos. Chem. Phys. 16, 455-504. https://doi.org/10.5194/acp-16-455-2016.

Mishchenko, M.I., Travis, L.D., Kahn, R.A., West, R. A., 1997. Modeling phase functions for dustlike tropospheric aerosols using a shape mixture of randomly oriented polydisperse spheroids. J. Geophys. Res. 102(D2), 16831-16847. https://doi.org/10.1029/96JD02110.

Mishchenko, M.I., Alexandrov, M.D., Cairns, B., Travis, L.D., 2016. Multistatic aerosol-cloud lidar in space: A theoretical perspective. J. Quant. Spectrosc. Radiat. Transfer., 184, 180-192. https://doi.org/10.1016/j.jqsrt.2016.07.015. 
Moled, A., Takacs, L., Suarez, M., Bacmeister, J., Song, I.-S, Eichmann, A., 2012. The GEOS-5 atmospheric general circulation model: Mean climate and development from MERRA to Fortuna. NASA/TM-2012-104606/Vol 28(Max Suarez, editor).

Moreira, G., Guerrero-Rascado, J.L., Bravo-Aranda, J.A., Benavent-Oltra, J.A., OrtizAmezcua, P., Róman, R., Bedoya-Velásquez, A.E., Landulfo, E., Alados-Arboledas, L., 2018. Study of the planetary boundary layer by microwave radiometer, elastic lidar and Doppler lidar estimations in Southern Iberian Peninsula, Atmos. Res., 213, 185-195.

Müller, D., Wandinger, U., Ansmann, A., 1999a. Microphysical particle parameters from extinction and backscatter lidar data by inversion with regularization: theory. Appl. Optics 38, (12), pp. 2346-2357, https://doi.org/10.1364/AO.38.002346.

Müller, D., Wandinger, U., Ansmann, A., 1999b: Microphysical particle parameters from extinction and backscatter lidar data by inversion with regularization: simulation. Appl. Optics 38, (12), pp. 2358-2368, https://doi.org/10.1364/AO.38.002358.

Müller, D., Böckmann, C., Kolgotin, A., Schneidenbach, L., Chemyakin, E., Rosemann, J., Znak, P., Romanov, A., 2016. Microphysical particle properties derived from inversion algorithms developed in the framework of EARLINET. Atmos. Meas. Tech. 9, 5007-5035. https://doi.org/10.5194/amt-9-5007-2016.

Nakajima, T., Tonna, G., Rao. T., Boi, P., Kaufman, Y., Holben, B., 1996. Use of sky brightness measurements from ground for remote sensing of particulate polydispersions. App. Optics 35, 2672-2686. https://doi.org/10.1364/AO.35.002672.

Navas-Guzmán, F., Bravo-Aranda, J. A., Guerrero-Rascado, J. L., Granados-Muñoz, M. J., Alados-Arboledas, L., 2013a: Statistical analysis of aerosol optical properties retrieved by Raman lidar over Southeastern Spain. Tellus B, 65, 21234, https://doi.org/10.3402/tellusb.v65i0.21234.

Navas-Guzmán, F., Müller, D., Bravo-Aranda, J.A., Guerrero-Rascado, J.L., GranadosMuñoz, M.J., Pérez-Ramírez, D., Olmo, F.J., Alados-Arboledas, L., 2013b. Eruption of 
the Eyjafjallajökull Volcano in spring 2010: Multiwavelength Raman lidar measurements of sulphate particles in the lower troposphere. J. of Geophys. Res. Atmospheres 118, 1804-1813. https://doi.org/10.1002/jgrd.50116.

O'Neill, N. T., Dubovik O., Eck, T.F., 2001. Modified Angstrom exponent for the characterization of submicrometer aerosols. Appl. Opt. 40, 2368-2375. https://doi.org/10.1364/AO.40.002368

O'Neill, N.T., 2010. Comment on "Classification of aerosol properties derived from AERONET direct sun data” by Gobbi et al. (2007). Atmos. Chem. Phys. 10, 1001710019. https://doi.org/10.5194/acp-10-10017-2010

Ortiz-Amezcua, P., Guerrero-Rascado, J. L., Granados-Muñoz, M. J., Benavent-Oltra, J. A., Böckmann, C., Samaras, S., Stachlewska, I. S., Janicka, L., Baars, H., Bohlmann, S., AladosArboledas, L., 2017. Microphysical characterization of long-range transported biomass burning particles from North America at three EARLINET stations. Atmos. Chem. Phys. 17, 5931-5946, https://doi.org/10.5194/acp-17-5931-2017.

Osterloh, L., Böckmann, C., Nicolae, D., Nemuc, A., 2013. Regularized inversion of microphysical atmospheric particle parameters: Theory and application. J. Comput. Phys. 237, 79-94. https://doi.org/10.1016/j.jcp.2012.11.040.

Pappalardo, G., Amodeo, A., Apituley, A., Comeron, A., Freudenthaler, V., Linné, H., Ansmann, A., Bösenberg, J., D’Amico, G., Mattis, I., Mona, L., Wandinger, U., Amiridis, V., AladosArboledas, L., Nicolae, D., Wiegner, M., 2014. EARLINET: towards an advanced sustainable European aerosol lidar network. Atmos. Meas. Tech. 7, 2389-2409, https://doi.org/10.5194/amt7-2389-2014.

Pawson, S., Stolarski, R.S., Douglass, A.R., Newman, P.A., Nielsen, J.E., Frith, S.M., Gupta, M.L., 2008. Goddard Earth Observing System chemistry-climate model simulations of stratospheric ozone-temperature coupling between 1950 and 2005. J. Geophys. Res. Atmospheres 113, D12103. https://dx.doi.org/10.1029/2007JD009511. 
Pérez-Ramírez, D., Whiteman, D.N., Veselovskii, I., Kolgotin, A., Korenskiy, M., Alados-Arboledas, L., 2013. Effects of systematic and random errors on the retrieval of particle microphysical properties from multiwavelength lidar measurements using inversion with regularization. Atmos. Meas. Tech. 6, 3039-3054. https://doi.org/10.5194/amt-6-3039-2013.

Pérez-Ramírez, D., Lyamani, H., Olmo, F.J., Whiteman, D.N., Alados-Arboledas, L., 2012. Columnar aerosol properties from sun-and-star photometry: statistical comparisons and day-to-night dynamic. Atmos. Chem. Phys. 12, 9719-9738. https://doi.org/10.5194/acp-12-9719-2012, 2012.

Pérez-Ramírez, D., Lyamani, H., Smirnov, A., O’Neill, N.T., Veselovskii, I., Whiteman, D.N., Olmo, F.J., Alados-Arboledas, L., 2016. Statistical study of day and night hourly patterns of columnar aerosol properties using sun and star photometry. Proc. SPIE 10001, Remote Sensing of Clouds and the Atmosphere XXI, 100010K. https://doi.org/10.1117/12.2242372.

Pérez-Ramírez, D., Whiteman, D.N., Veselovskii, I., Colarco, P., Korenski, M., da Silva, A., 2019. Retrievals of single scattering albedo by multiwavelength LIDAR measurements: evaluation with NASA Langley HSRL-2 during DISCOVER-AQ field campaigns. Remote Sens. Environ. 222, 144-164, doi:10.1016/j.rse.2018.12.022. https:// doi.org/10.1016/j.rse.2018.12.022

Perrone, M. R., de Tomasi, F., Gobbi, G. P., 2014. Vertically resolved aerosol properties by multi-wavelength lidar measurements. Atmos. ChemPhys. 14, 1185-1204, doi:10.5194/acp-14-1185-2014. https://doi.org/10.5194/acp-14-1185-2014.

Quirantes, A., Olmo, F. J., Valenzuela, A., Lyamani, H., Alados-Arboledas, L., 2010. ALFA/BETA: a dual databasefor light scatteringsimulationsonatmosphericaerosols, Proceedings IV Reunión Española de Ciencia y Tecnología del Aerosol (RECTA 2010), D4-1 - D4-4. 
Quirantes, A., Olmo, F. J., Lyamani, H., Valenzuela, A., Alados-Arboledas, L., 2012: Investigation of fine and coarse aerosol contributions to the total aerosol light scattering: Shape effects and concentration profiling by Raman lidar measurements. J. Quant. Spectrosc. Radiat. Transfer 113, 2593-2600, doi:10.1016/j.jqsrft.2012.08.010. https://doi.org/10.1016/j.jqsrt.2012.08.010.

Rienecker, M.M., Suarez, M.J. Gelaro, R., Todling, R., Bacmeister, J., Liu, E., Bosilovich, M.G., Schubert, S.D., Takacs, L., Kim, G.-K, Bloom, S., Chen, J., Collins, D., Conaty, A., Da Silva, A., Gu, W., Joiner, J., Koster, R.D., Lucchesi, R., Molod, A., Owens, T., Pawson, S., Pegion, P., Redder, C.R., Reichle, R., Robertson, F.R., Ruddick, A.G., Sienkiewicz, M. Woolen, J., 2011: MERRA: NASA’s Modern-Era Retrospective Analysis for Research and Applications. J. Climate 24, 3624-3648. https://doi.org/10.1175/JCLI-D-11-00015.1.

Shaw, G., E., Reagan, J.A., Herman, B.M., 1973. Investigations of atmospheric extinction using direct solar radiation measurements made with a multiple wavelength radiometer. J. Appl. Meteor. 12, 374-380. https://doi.org/10.1175/15200450(1973)012<0374:IOAEUD>2.0.CO;2.

Shaw, G.E., 1979. Inversion of optical scattering and spectral extinction measurements to recover aerosol size spectra. Appl. Opt. 18, 988-993. https://doi.org/10.1364/AO.18.000988.

Shimizu, A., Sugimoto, N., Matsui, I., Arao, K., Uno, I., Murayama, T., Kagawa, N., Aoki, K., Uchiyama, A., Yamazaki, A., 2004: Continuous observations of Asian dust and other aerosols by polarization lidars in China and Japan during ACE-Asia. J. Geophys. Res. 109, D19S17. https://doi.org/10.1029/2002JD003253.

Sicard, M., Molero, F., Guerrero-Rascado, J. L., Pedrós, R., Expósito, F. J., CórdobaJabonero, C., Bolarín, J. M., Comerón, A., Rocadenbosh, F., Pujadas, M., AladosArboledas, L., MartínezLozano, J. A., Díaz, J. P., Gil, M., Requena, A., Navas-Guzman, F., Moreno, J. M., 2009. Aerosol lidar intercomparison in the framework of 
SPALINET-The Spanish lidar network: Methodology and results. IEEE T. Geosci. Remote 47, 3547-3559. https://doi.org/10.1109/TGRS.2009.2021525

Titos, G., Foyo-Moreno, I., Lyamani, H., Querol, X., Alastuey, A., Alados-Arboledas, L., 2012. Optical properties and chemical composition of aerosol particles at an urban location: An estimation of the aerosol mass scattering and absorption efficiencies. J. Geophys. Res. Atmospheres 117, D04206, https://doi.org/10.1029/2011JD016671.

Titos, G., del Águila, A., Cazorla, A., Lyamani, H., Casquero-Vera, J. A., Colombi, C., Cuccia, E., Gianelle, V., Alastuey, A., Alasdos-Arboledas, L., 2017. Spatial and temporal variability of carbonaceous aerosols: assessing the impact of biomass burning in the urban environment. Sci. Total Environ. 578, 613-625. https://doi.org/10.1016/j.scitotenv.2016.11.007.

Valenzuela, A., Olmo, F. J., Lyamani, H., Granados-Muñoz, M. J., Antón, M., Guerrero-Rascado, J. L., Quirantes, A., Toledano, C., Perez-Ramírez, D., AladosArboledas, L., 2014. Aerosol transport over the western mediterranean basin: Evidence of the contribution of fine particles to desert dust plumes over Alboránisland. J. Geophys. Res. 119, 14028-14044. https://doi.org/10.1002/2014JD022044.

Veselovskii, I., Kolgotin, A., Griaznov, V., Muller, D., Wandinger, U., Whiteman, D., 2002. Inversion with regularization for the retrieval of tropospheric aerosol parameters from multiwavelength lidar sounding. Appl. Opt. 41, 3685-3699. https://doi.org/10.1364/A0.41.003685.

Veselovskii, I., Goloub, T., Podvin, T., Tanré, D., da Silva, A., Colarco, P., Castellanos, P., Korenskiy, M., Hu, Q., Whiteman, D.N., Pérez-Ramírez, D., Augustin, P., Fourmentin, M., Kolgotin, A., 2018. Characterization of smoke and dust episode over West Africa: comparison of MERRA-2 modeling with multiwavelength Mie-Raman lidar observations. Atmosph. Meas. Tech., 11, 949-969. https://doi.org/10.5194/amt-11949-2018. 
Whiteman, D.N., Pérez-Ramírez, D., Veselovskii, I., Colarco, P., Buchard, V., 2018. Retrievals of aerosol microphysics from simulations of spacebornemultiwavelength lidar measurements. J. Quant. Spectrosc. Radiat. Transfer 205, 27-39. https://doi.org/10.1016/j.jqsrt.2017.09.009.

Waterman, P. C., 1971. Symmetry, unitarity, and geometry in electromagnetic scattering. Phys. Rev. D 3, 825-839. https://doi.org/10.1103/PhysRevD.3.825. 


\section{TABLES}

Table 1. Values of a particular particle size distribution (volume log-normal, bimodal)

\begin{tabular}{|c|c|c|}
\hline & Fine mode & Coarse mode \\
\hline $\mathrm{R}_{\mathrm{v}}(\mu \mathrm{m})$ & 0,097 & 1,295 \\
\hline $\mathrm{Ln}(\sigma)$ & 0,726 & 0,549 \\
\hline Refractiveindex & $1,478+\mathrm{i} 0.0005$ & $1.518+\mathrm{i} 0.0005$ \\
\hline
\end{tabular}

Table 2. Values of the Gobbi grid points for several values of the coarse mode radius $R_{c}$ assuming parameters $\mathrm{R}_{\mathrm{f}}=0.05 \mu \mathrm{m}, \mathrm{F}_{\mathrm{v}}=30 \%$ and $\mathrm{m}=1.4+\mathrm{i} 0.001$

\begin{tabular}{|c|c|c|}
\hline $\mathrm{R}_{\mathrm{c}}(\mu \mathrm{m})$ & $\mathrm{AE}_{\mathrm{AOD}}(440,870)$ & $\Delta \mathrm{AE}_{\mathrm{AOD}}$ \\
\hline 1 & 1.053 & 0.704 \\
\hline 2 & 2.200 & 0.576 \\
\hline 4 & 2.579 & 0.209 \\
\hline
\end{tabular}

Table 3. $\mathrm{AE}_{\mathrm{AOD}}-\triangle \mathrm{AE}_{\mathrm{AOD}}$ grid points for Figure 6 (Gobbi diagram parameters, volume fraction values) Wavelengths: $440,675,870 \mathrm{~nm} . \mathrm{m}=1.402+\mathrm{i} 0.00105$

\begin{tabular}{cccccccc}
\hline $\mathrm{F}_{\mathrm{v}}$ & $\mathrm{Rf}=0.05 \mu \mathrm{m}$ & $\mathrm{Rf}=0.1 \mu \mathrm{m}$ & $\mathrm{Rf}=0.15 \mu \mathrm{m}$ & $\mathrm{Rf}=0.2 \mu \mathrm{m}$ & $\mathrm{Rf}=0.3 \mu \mathrm{m}$ & $\mathrm{Rf}=0.4 \mu \mathrm{m}$ & $\mathrm{Rf}=0.5 \mu \mathrm{m}$ \\
\hline $1 \%$ & $(-0.065,0.066)$ & $(0.024,0.124)$ & $(0.084,0.131)$ & $(0.101,0.102)$ & $(0.063,0.025)$ & $(-0.003,-0.024)$ & $(-0.057,-0.038)$ \\
\hline $10 \%$ & $(2.241,0.328)$ & $(0.747,0.465)$ & $(0.921,0.305)$ & $(0.901,0.116)$ & $(0.652,-0.149)$ & $(0.361,-0.280)$ & $(0.121,-0.309)$ \\
\hline $30 \%$ & $(0.821,0.687)$ & $(1.556,0.499)$ & $(1.624,0.140)$ & $(1.471,-0.104)$ & $(1.022,-0.367)$ & $(0.591,-0.482)$ & $(0.243,-0.499)$ \\
\hline $50 \%$ & $(1.374,0.867)$ & $(2.054,0.333)$ & $(1.969,-0.057)$ & $(1.718,-0.270)$ & $(1.166,-0.479)$ & $(0.680,-0.571)$ & $(0.292,-0.577)$ \\
\hline $70 \%$ & $(1.986,0.876)$ & $(2.433,0.094)$ & $(2.189,-0.231)$ & $(1.863,-0.390)$ & $(1.246,-0.549)$ & $(0.279,-0.622)$ & $(0.319,-0.621)$ \\
\hline $90 \%$ & $(2.803,0.535)$ & $(2.756,-0.200)$ & $(2.348,-0.383)$ & $(1.960,-0.481)$ & $(1.296,-0.596)$ & $(0.759,-0.655)$ & $(0.337,-0.649)$ \\
\hline $99 \%$ & $(3.369,0.006)$ & $(2.891,-0.351)$ & $(2.407,-0.444)$ & $(1.994,-0.515)$ & $(1.313,-0.613)$ & $(0.770,-0.667)$ & $(0.343,-0.659)$ \\
\hline
\end{tabular}


Table 4. $\mathrm{AE}_{\mathrm{AOD}}-\triangle \mathrm{AE}_{\mathrm{AOD}}$ grid points for Figure 7, for a coarse mode log-normal distribution as given by OPAC Mineral-transported (MITR), m=1.44+i0.0097, Wavelengths: 440, 675, $870 \mathrm{~nm}$.

\begin{tabular}{ccccccccc}
\hline $\mathrm{F}_{\mathrm{v}}$ & $\mathrm{Rf}=0.05 \mu \mathrm{m}$ & $\mathrm{Rf}=0.1 \mu \mathrm{m}$ & $\mathrm{Rf}=0.15 \mu \mathrm{m}$ & $\mathrm{Rf}=0.2 \mu \mathrm{m}$ & $\mathrm{Rf}=0.3 \mu \mathrm{m}$ & $\mathrm{Rf}=0.4 \mu \mathrm{m}$ & $\mathrm{Rf}=0.5 \mu \mathrm{m}$ \\
\hline $1 \%$ & $(-0.102,0.038)$ & $(-0.048,0.074)$ & $(-0.014,0.077)$ & $(-0.008,0.057)$ & $(-0.038,0.008)$ & $(-0.078,-0.018)$ & $(-0.108,-0.020)$ \\
\hline $10 \%$ & $(0.117,0.225)$ & $(0.517,0.403)$ & $(0.680,0.296)$ & $(0.665,0.124)$ & $(0.441,-0.128)$ & $(0.190,-0.235)$ & $(0.002,-0.235)$ \\
\hline $30 \%$ & $(0.601,0.564)$ & $(1.320,0.548)$ & $(1.423,0.179)$ & $(1.280,-0.090)$ & $(0.832,-0.363)$ & $(0.416,-0.458)$ & $(0.104,-0.438)$ \\
\hline $50 \%$ & $(1.105,0.785)$ & $(1.849,0.403)$ & $(1.804,-0.035)$ & $(1.554,-0.273)$ & $(0.990,-0.489)$ & $(0.508,-0.558)$ & $(0.147,-0.526)$ \\
\hline $70 \%$ & $(1.665,0.847)$ & $(2.249,0.159)$ & $(2.042,-0.223)$ & $(1.711,-0.403)$ & $(1.075,-0.564)$ & $(0.557,-0.615)$ & $(0.171,-0.575)$ \\
\hline $90 \%$ & $(2.342,0.630)$ & $(2.573,-0.123)$ & $(2.208,-0.378)$ & $(1.814,-0.498)$ & $(1.128,-0.614)$ & $(0.589,-0.651)$ & $(0.186,-0.606)$ \\
\hline $99 \%$ & $(2.720,0.365)$ & $(2.701,-0.255)$ & $(2.268,-0.438)$ & $(1.850,-0.532)$ & $(1.147,-0.632)$ & $(0.599,-0.664)$ & $(0.191,-0.617)$ \\
\hline
\end{tabular}

Table 5. Same as Table 4, for wavelengths: 355, 532, $1064 \mathrm{~nm}$.

\begin{tabular}{cccccccc}
\hline $\mathrm{F}_{\mathrm{v}}$ & $\mathrm{Rf}=0.05 \mu \mathrm{m}$ & $\mathrm{Rf}=0.1 \mu \mathrm{m}$ & $\mathrm{Rf}=0.15 \mu \mathrm{m}$ & $\mathrm{Rf}=0.2 \mu \mathrm{m}$ & $\mathrm{Rf}=0.3 \mu \mathrm{m}$ & $\mathrm{Rf}=0.4 \mu \mathrm{m}$ & $\mathrm{Rf}=0.5 \mu \mathrm{m}$ \\
\hline $1 \%$ & $(-0.089,0.077)$ & $(-0.033,0.133)$ & $(-0.007,0.118)$ & $(-0.009,0.073)$ & $(0.044,-0.006)$ & $(-0.079,-0.031)$ & $(-0.103,-0.022)$ \\
\hline $10 \%$ & $(0.176,0.457)$ & $(0.536,0.612)$ & $(0.643,0.354)$ & $(0.606,0.073)$ & $(0.385,-0.280)$ & $(0.164,-0.378)$ & $(0.009,-0.318)$ \\
\hline $30 \%$ & $(0.680,0.975)$ & $(1.259,0.682)$ & $(1.323,0.115)$ & $(1.186,-0.264)$ & $(0.769,-0.636)$ & $(0.392,-0.712)$ & $(0.123,-0.602)$ \\
\hline $50 \%$ & $(1.145,1.193)$ & $(1.740,0.435)$ & $(1.698,-0.184)$ & $(1.470,-0.520)$ & $(0.938,-0.819)$ & $(0.492,-0.861)$ & $(0.175,-0.727)$ \\
\hline $70 \%$ & $(1.637,1.157)$ & $(2.131,0.102)$ & $(1.956,-0.441)$ & $(1.647,-0.703)$ & $(1.035,-0.929)$ & $(0.549,-0.945)$ & $(0.204,-0.797)$ \\
\hline $90 \%$ & $(2.253,0.788)$ & $(2.487,-0.279)$ & $(2.151,-0.658)$ & $(1.769,-0.839)$ & $(1.098,-1.003)$ & $(0.585,-0.999)$ & $(0.224,-0.843)$ \\
\hline $99 \%$ & $(2.634,0.424)$ & $(2.644,-0.465)$ & $(2.225,-0.745)$ & $(1.813,-0.889)$ & $(1.120,-1.029)$ & $(0.597,-1.018)$ & $(0.230,-0.858)$ \\
\hline
\end{tabular}




\section{FIGURES}

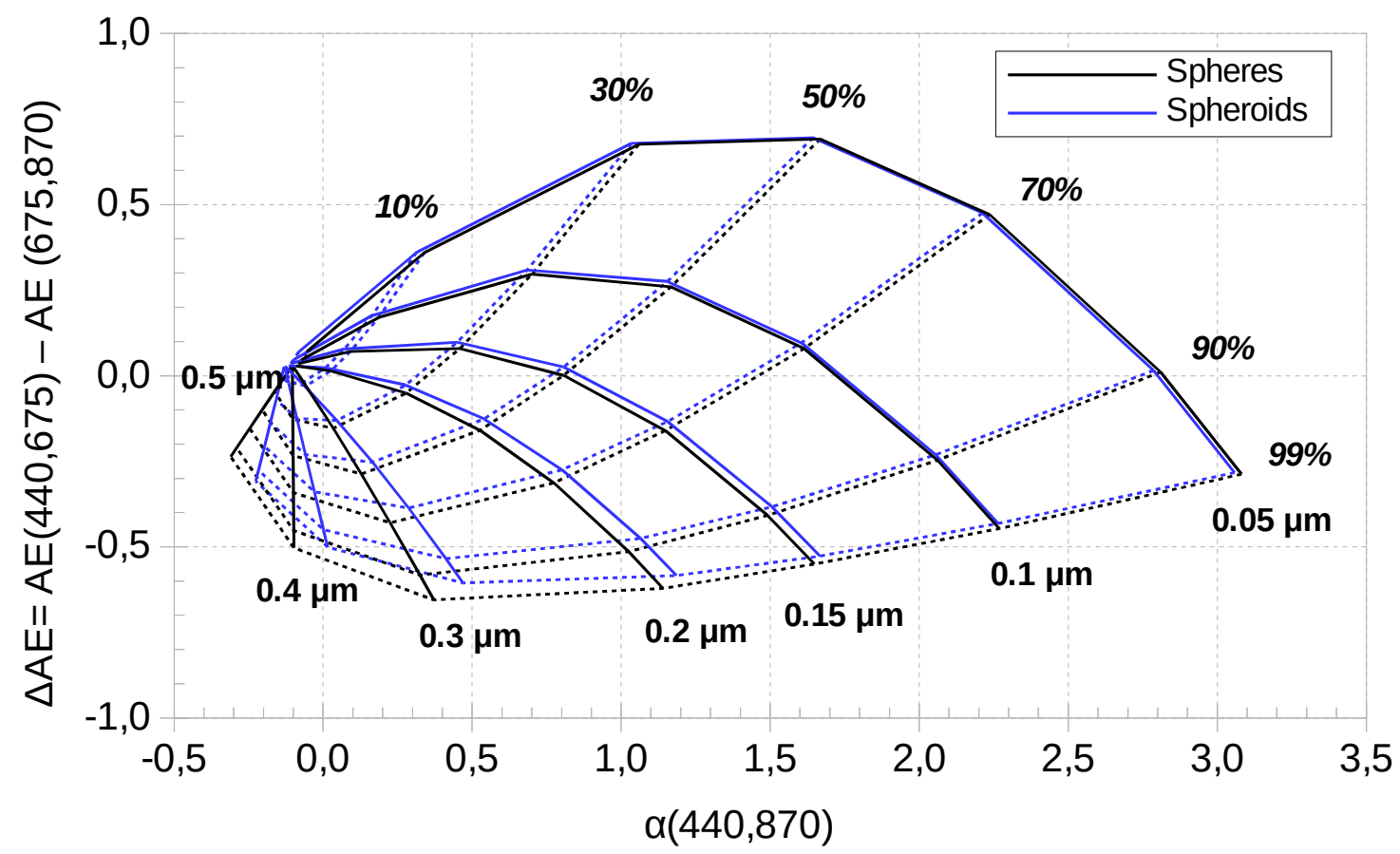

Fig 1. $\mathrm{AE}_{\mathrm{AOD}}-\triangle \mathrm{AE}_{\mathrm{AOD}}$ grid diagram for spheres (black) and for a $50-50$ volume mixture of oblate+prolate spheroids with an axial ratio 1.8 (blue). $\mathrm{m}=1.402+\mathrm{i} 0.00105$. Size distribution values are those of Gobbi et al. (2007). 
Fig. $2 \mathrm{AE}_{\mathrm{AOD}}-\triangle \mathrm{AE}_{\mathrm{AOD}}$ grid diagram for three bimodal distributions of spherical

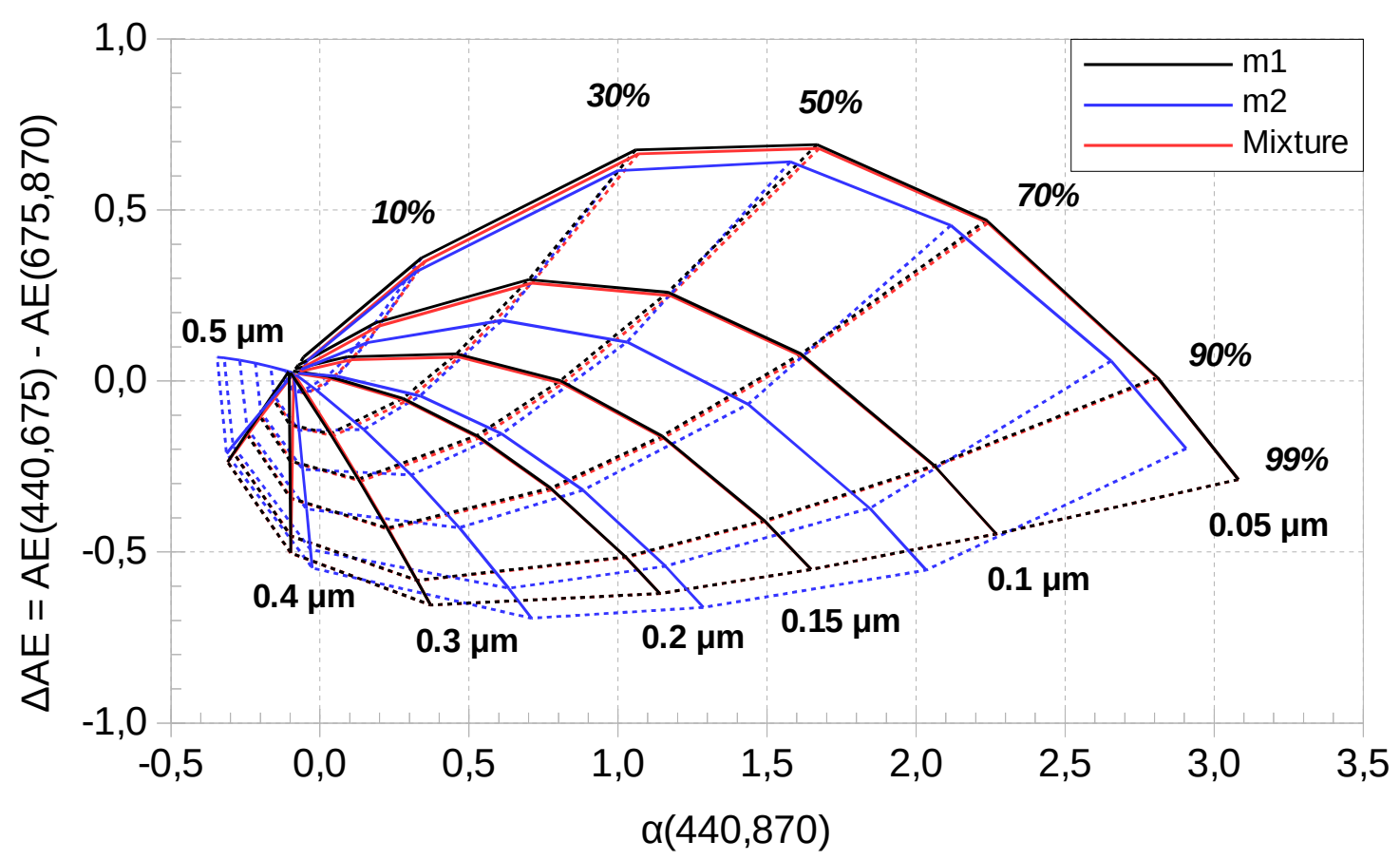

particles with index of refraction $\mathrm{m} 1=1.4+\mathrm{i} 0.001, \mathrm{~m} 2=1.518+\mathrm{i} 0.0097$. Black: $\mathrm{m} 1$ for both modes. Blue: $\mathrm{m} 2$ for both modes. Red: $\mathrm{m} 1$ for fine mode, $\mathrm{m} 2$ for coarse mode. 


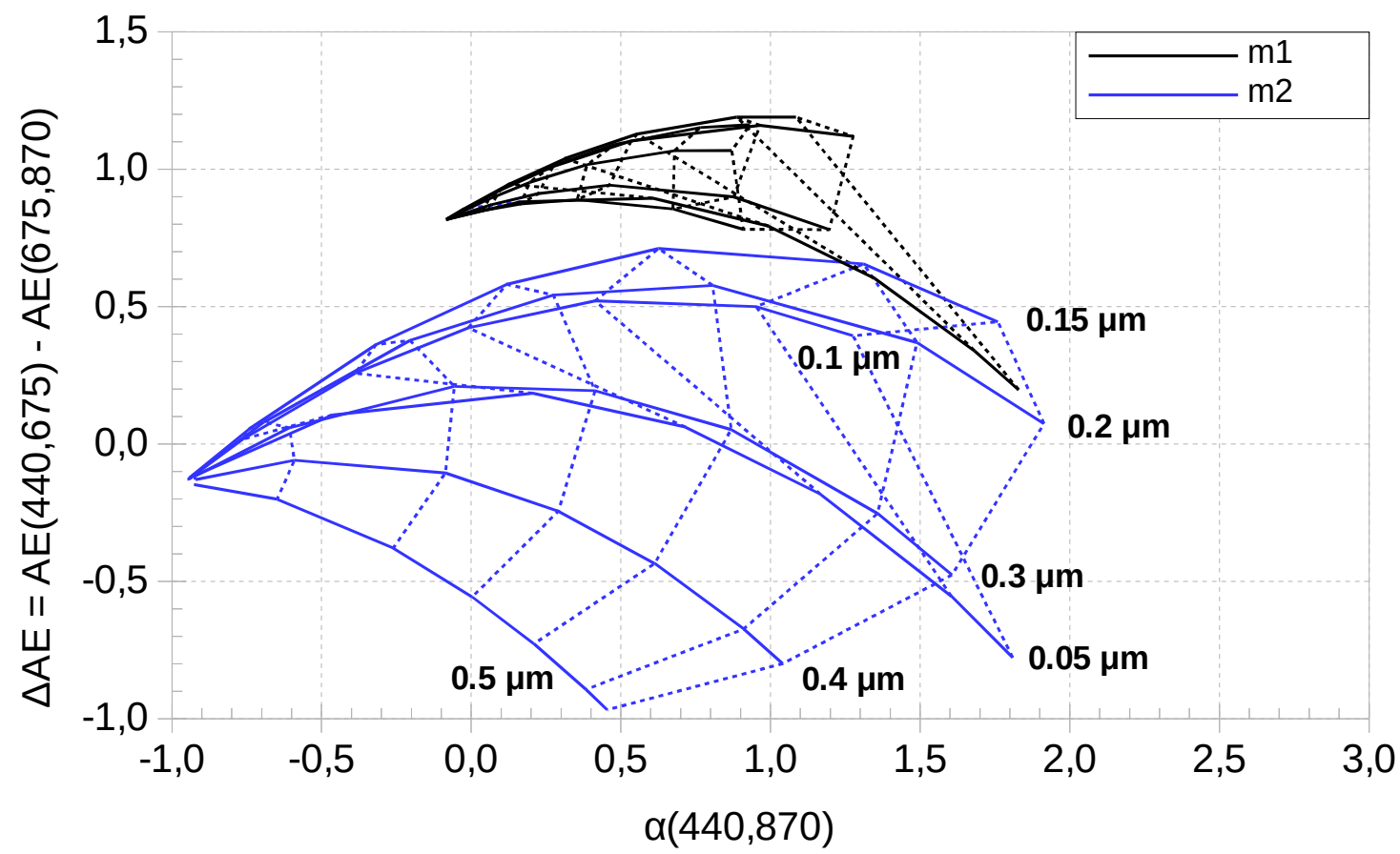

Fig 3. Ångström backscattering for refractive index values m1=1.4+i0.001 (black), $\mathrm{m} 2=1.518+\mathrm{i} 0.0097$ (blue). $\mathrm{m} 1$ values have been shifted upwards $(\Delta \mathrm{AE}=+1)$ for ease of viewing. 
Fig 4. Ångström backscattering at m=1.4+i0.001 for spheres (black) and spheroids

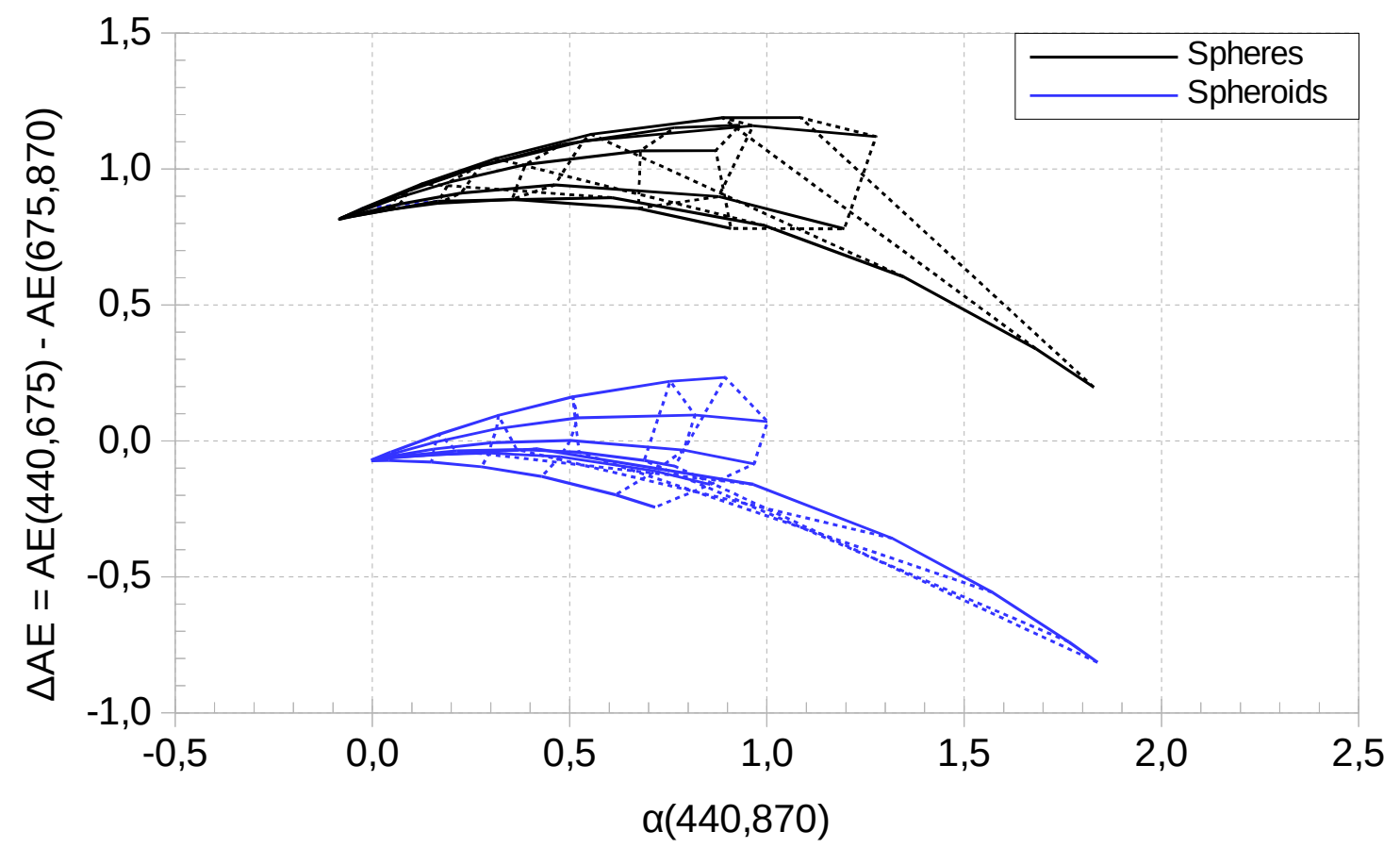

(blue). Values for spheres have been shifted upwards $(\triangle \mathrm{AE}=+1)$ for ease of viewing. 


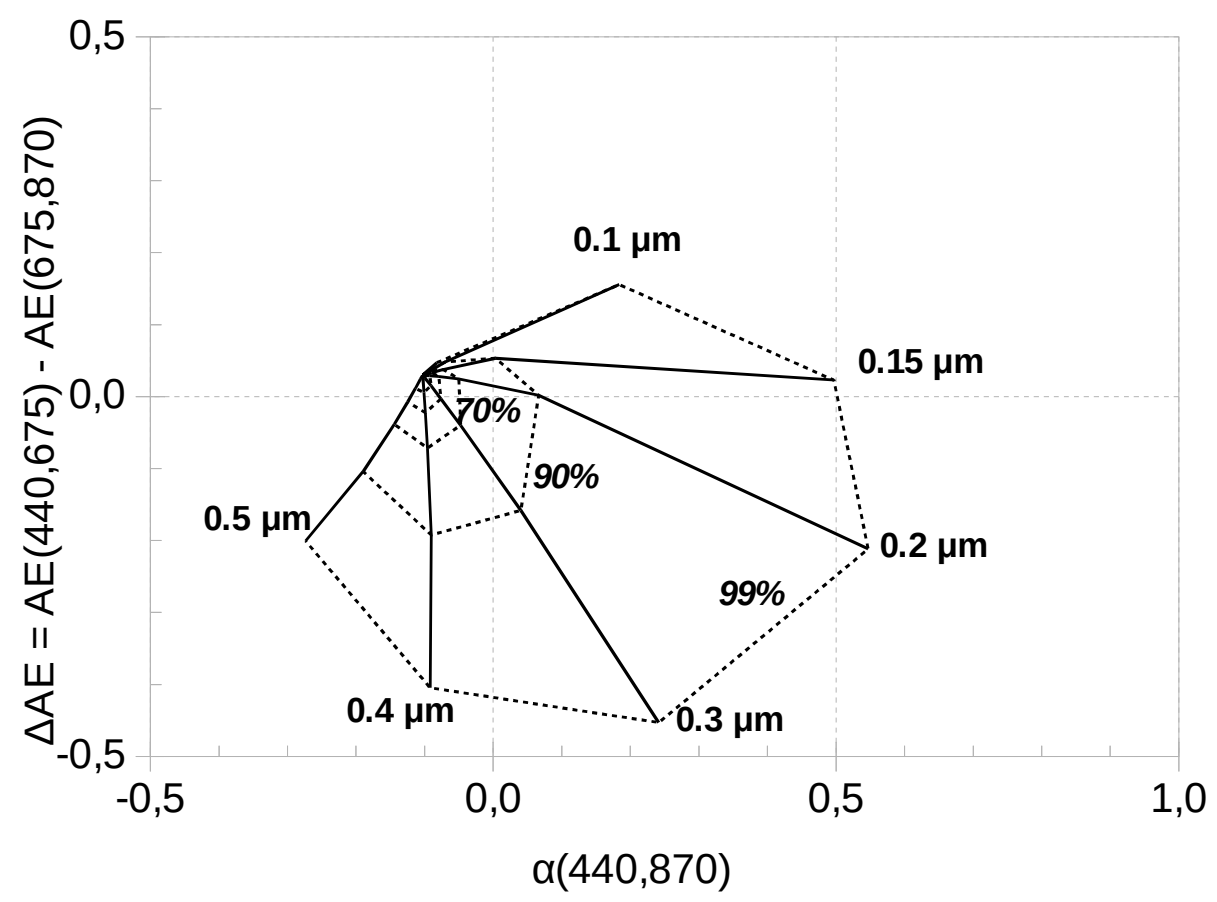

Fig.5 $\mathrm{AE}_{\mathrm{AOD}}-\triangle \mathrm{AE}_{\mathrm{AOD}}$ grid for constant number fraction values (dotted lines). Same size/composition parameters as the original Gobbi diagram. 
Fig. $6 \mathrm{AE}_{\mathrm{AOD}}-\triangle \mathrm{AE} \mathrm{E}_{\mathrm{AOD}}$ grid for constant volume fraction values (dotted lines). Same size/composition parameters as the original Gobbi diagram.

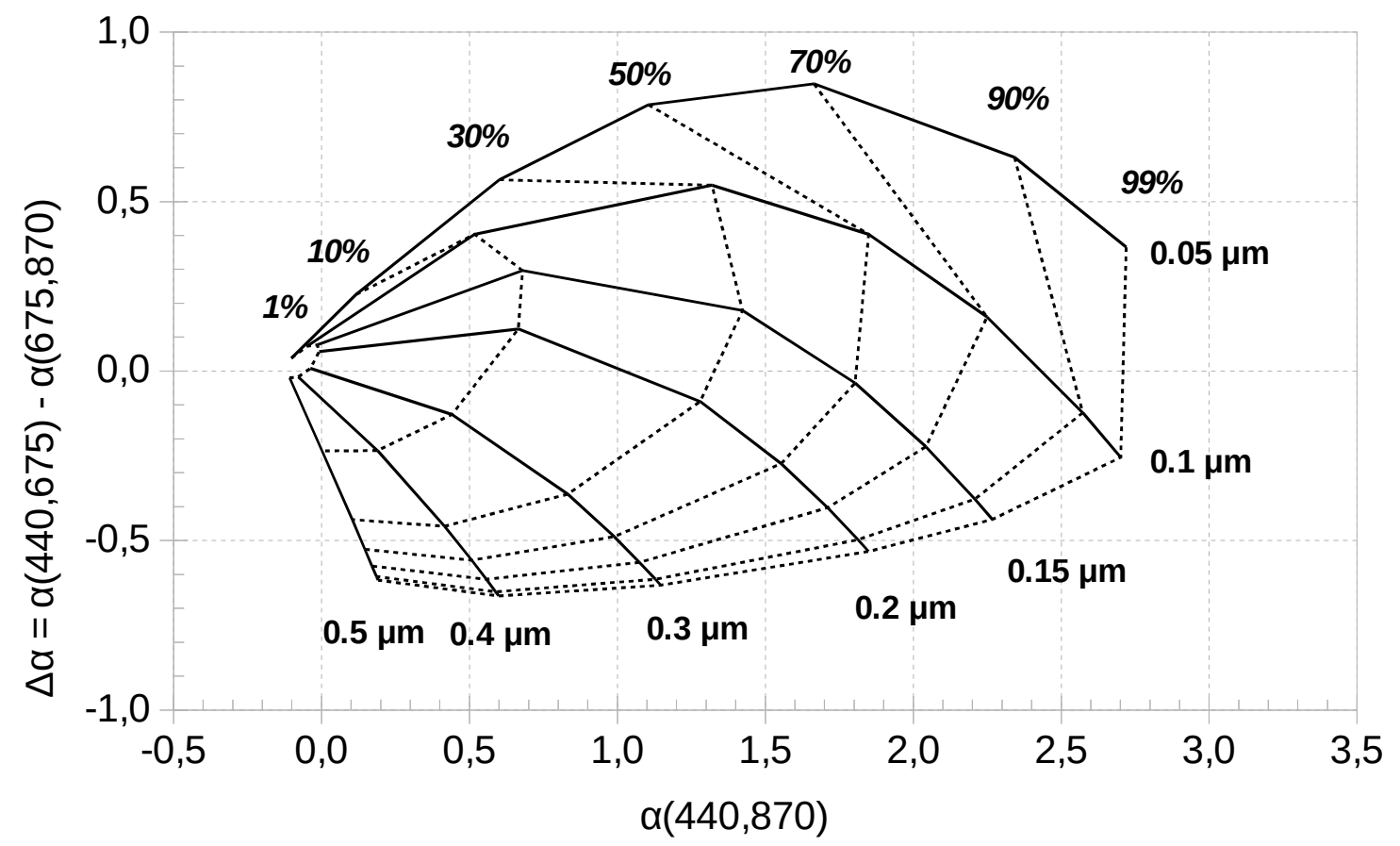

Fig. $7 \mathrm{AE}_{\mathrm{AOD}}-\triangle \mathrm{AE}_{\mathrm{AOD}}$ grid (constant volume fraction plot) for OPAC MITR (mineral, transported) model $\mathrm{m}=1.44+\mathrm{i} 0.0097$. 


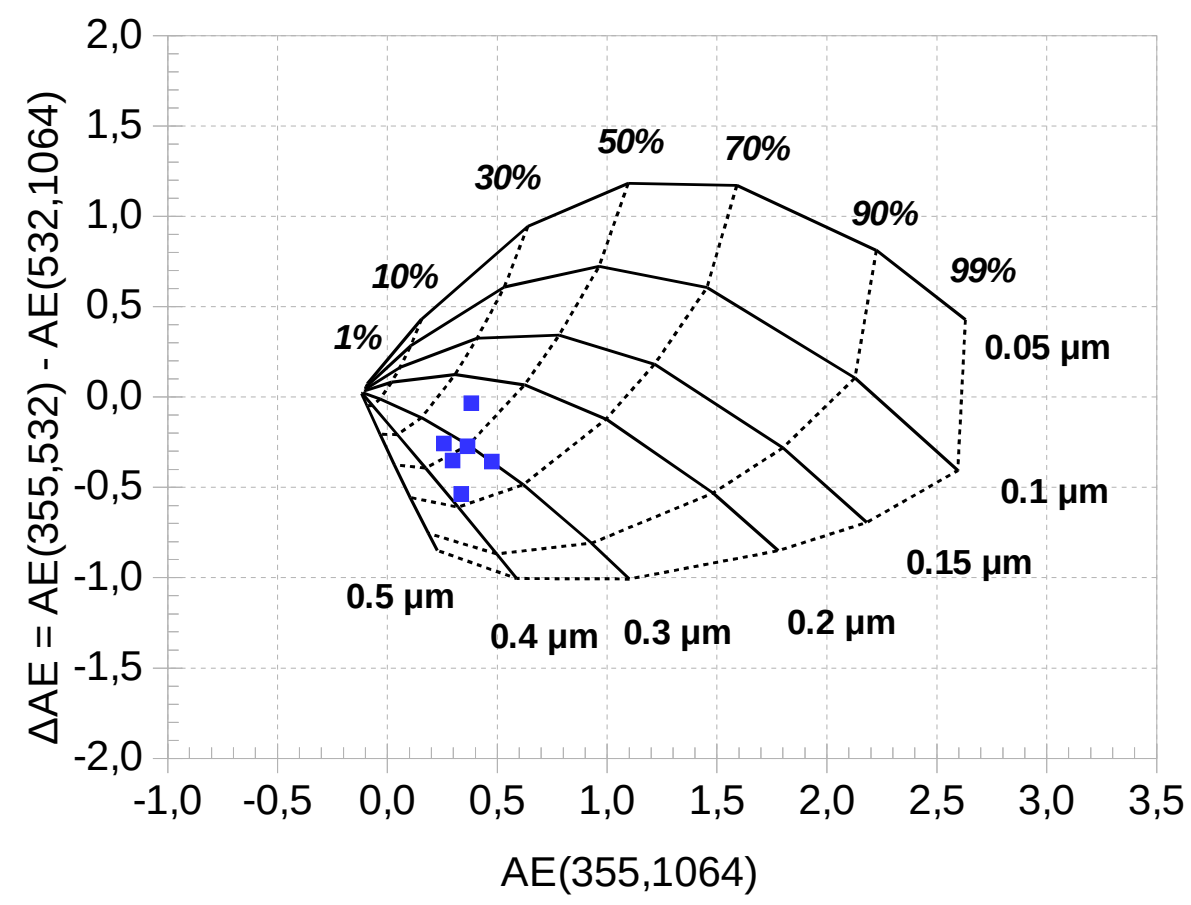

Fig. 8a $\mathrm{AE}_{\mathrm{AOD}}-\triangle \mathrm{AE}_{\mathrm{AOD}}$ grid (constant AOD fraction plot) for OPAC MITR (mineral, transported) model $\mathrm{m}=1.442+\mathrm{i} 0.0097$, and experimental data.

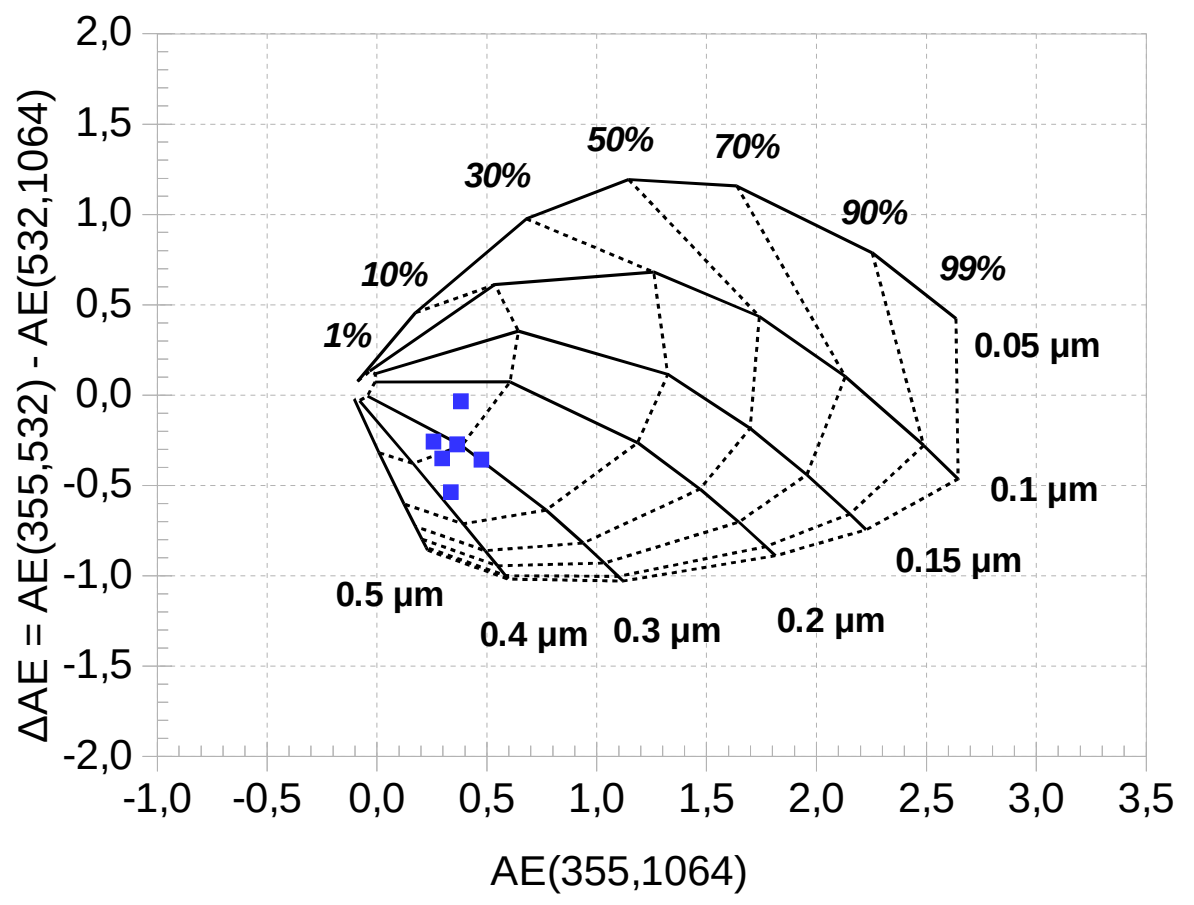


Fig. 8b $\mathrm{AE}_{\mathrm{AOD}}-\triangle \mathrm{AE}_{\mathrm{AOD}}$ grid (constant volume fraction plot) for OPAC MITR (mineral, transported) model $\mathrm{m}=1.44+\mathrm{i} 0.0097$, and experimental data.

Figure 9: (a) Backscattering, (b) extinction and (c) fraction of each aerosol specie profile for a dust outbreaks over Africa from GEOS-5 simulated data.
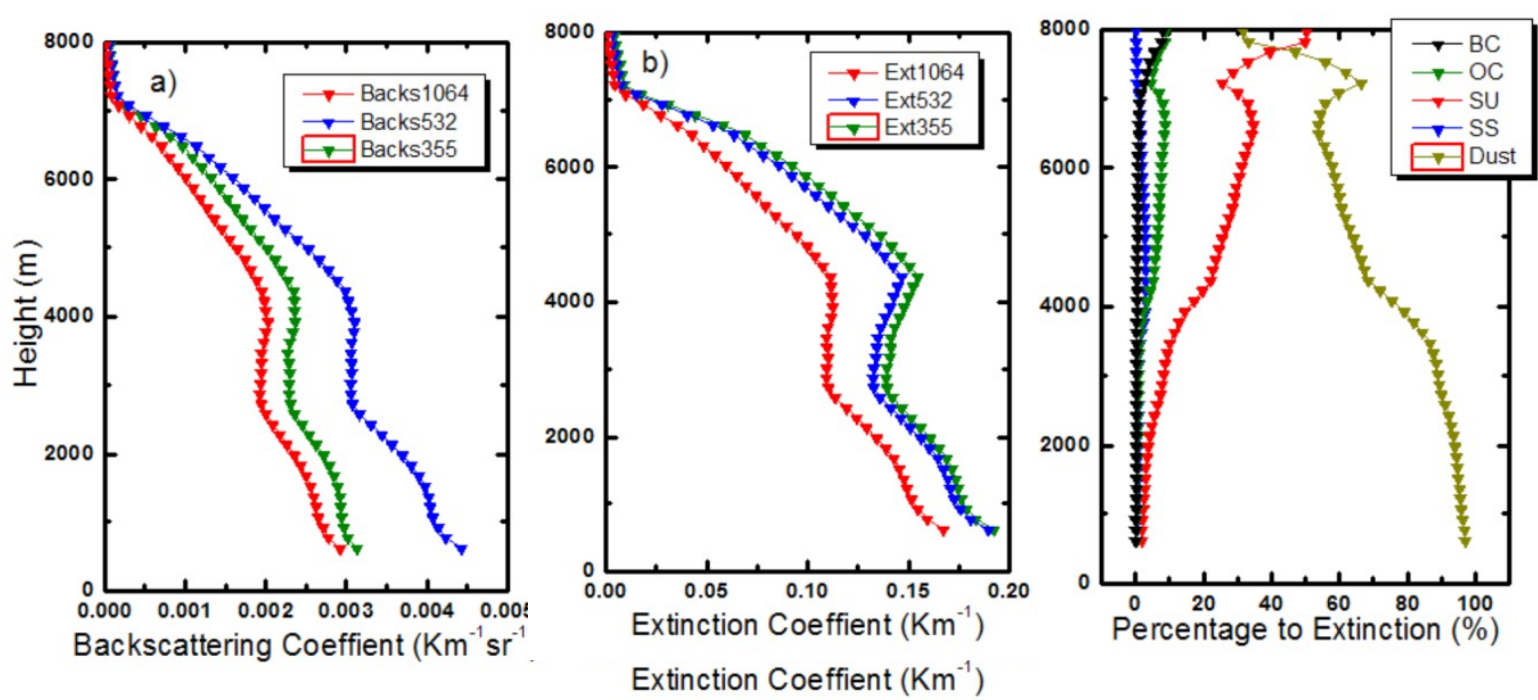



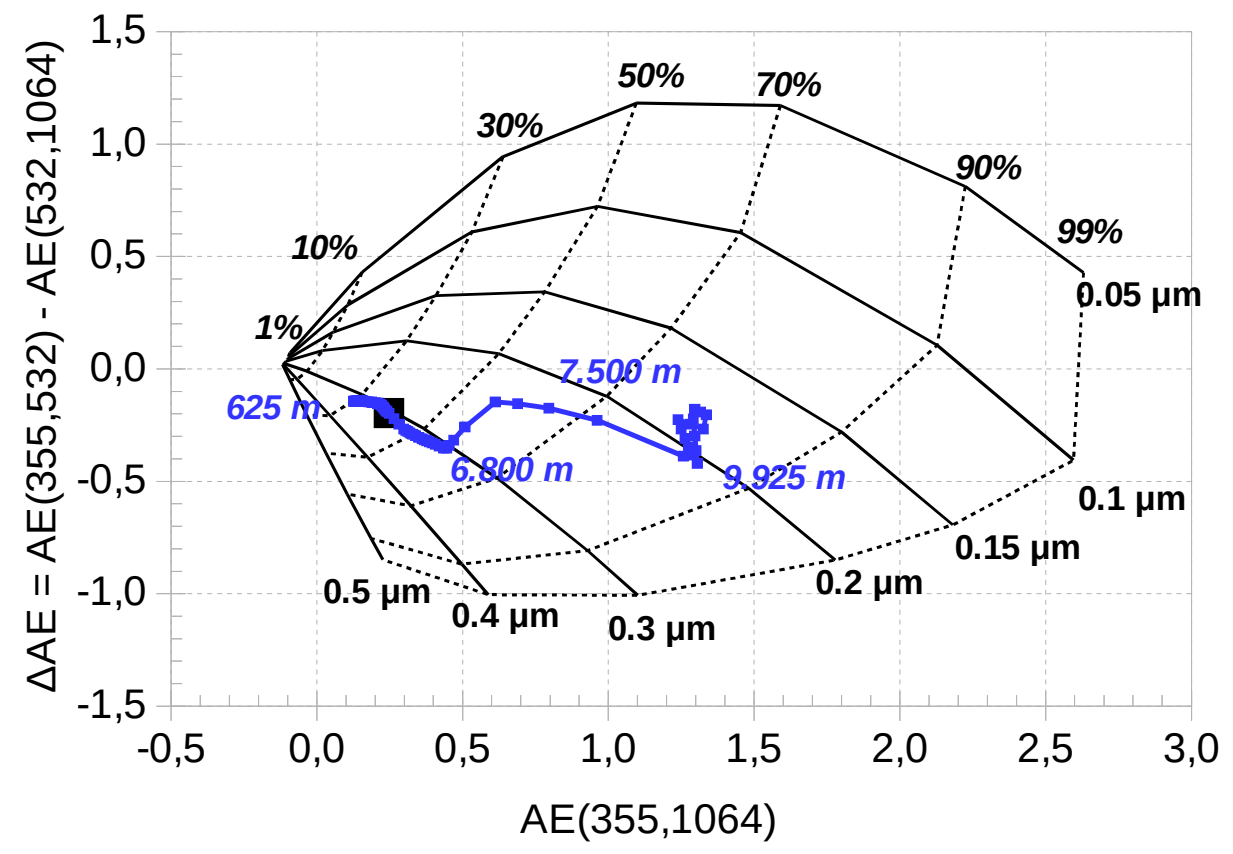

Fig. 10a $\mathrm{AE}_{\mathrm{AOD}}-\triangle \mathrm{AE}_{\mathrm{AOD}}$ grid (classical Gobbi plot) for a simulated dust outburst based on GEOS-5 data.

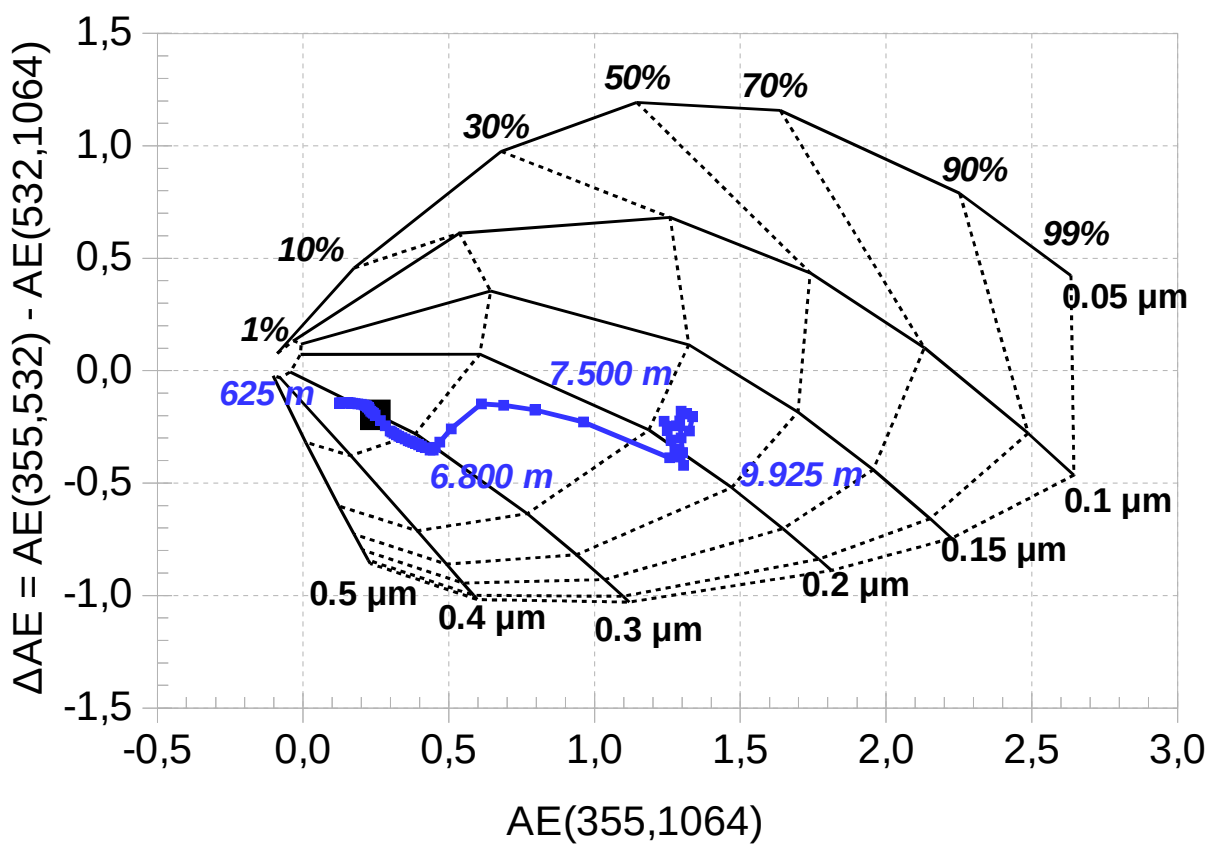


Fig. 10b Same as Fig. 10a for a constant-volume-fraction grid.
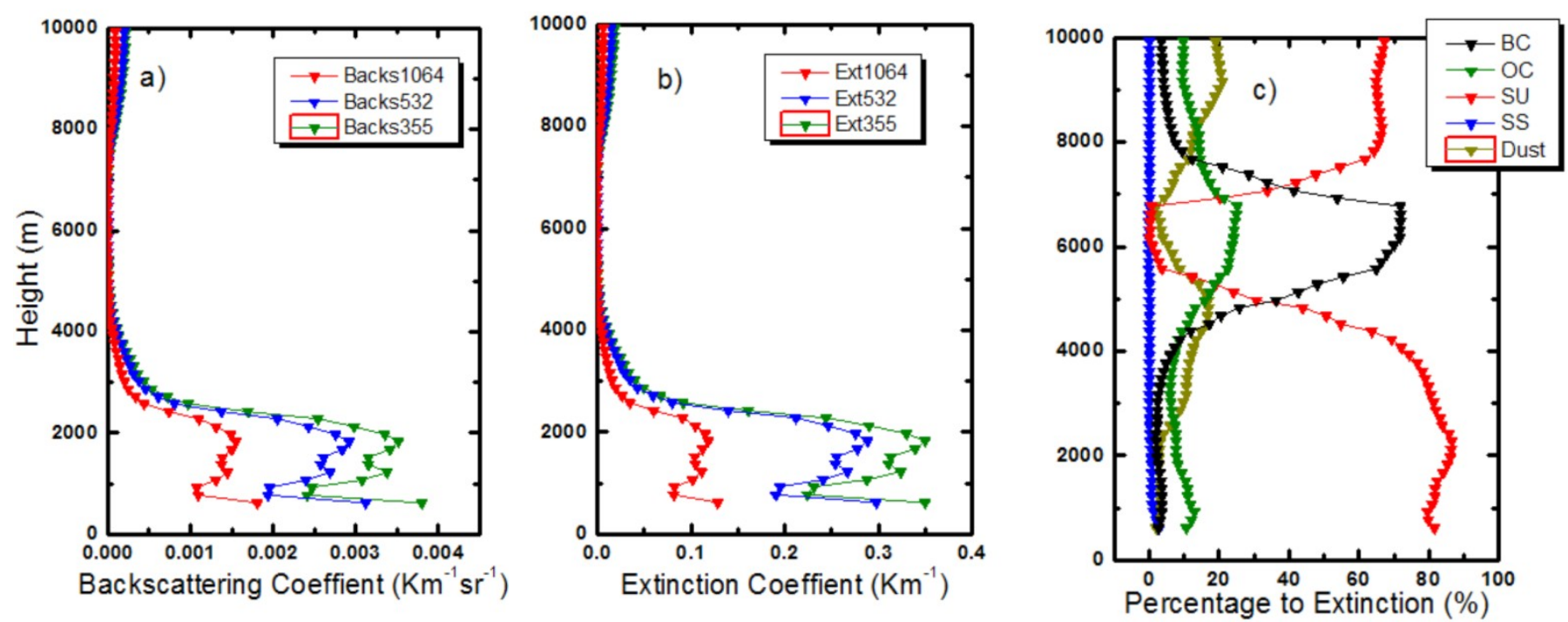
Figure 11: (a) Backscattering, (b) extinction and (c) fraction of each aerosol specie profile for pollution study cases over East Asia from GEOS-5 simulated data. 


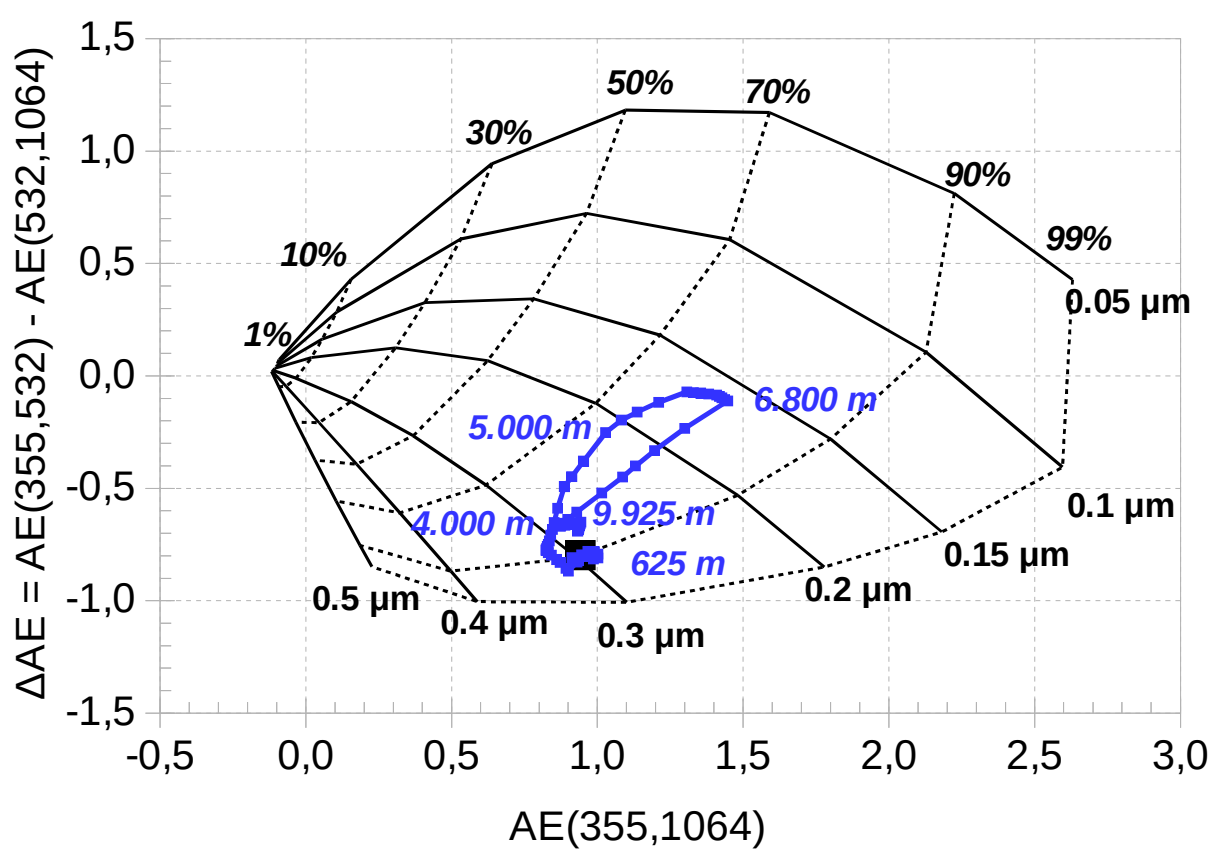

Fig. 12a $\mathrm{AE}_{\mathrm{AOD}}-\triangle \mathrm{AE}_{\mathrm{AOD}}$ grid (classical Gobbi plot) for a simulated pollution episode based on GEOS-5 data.

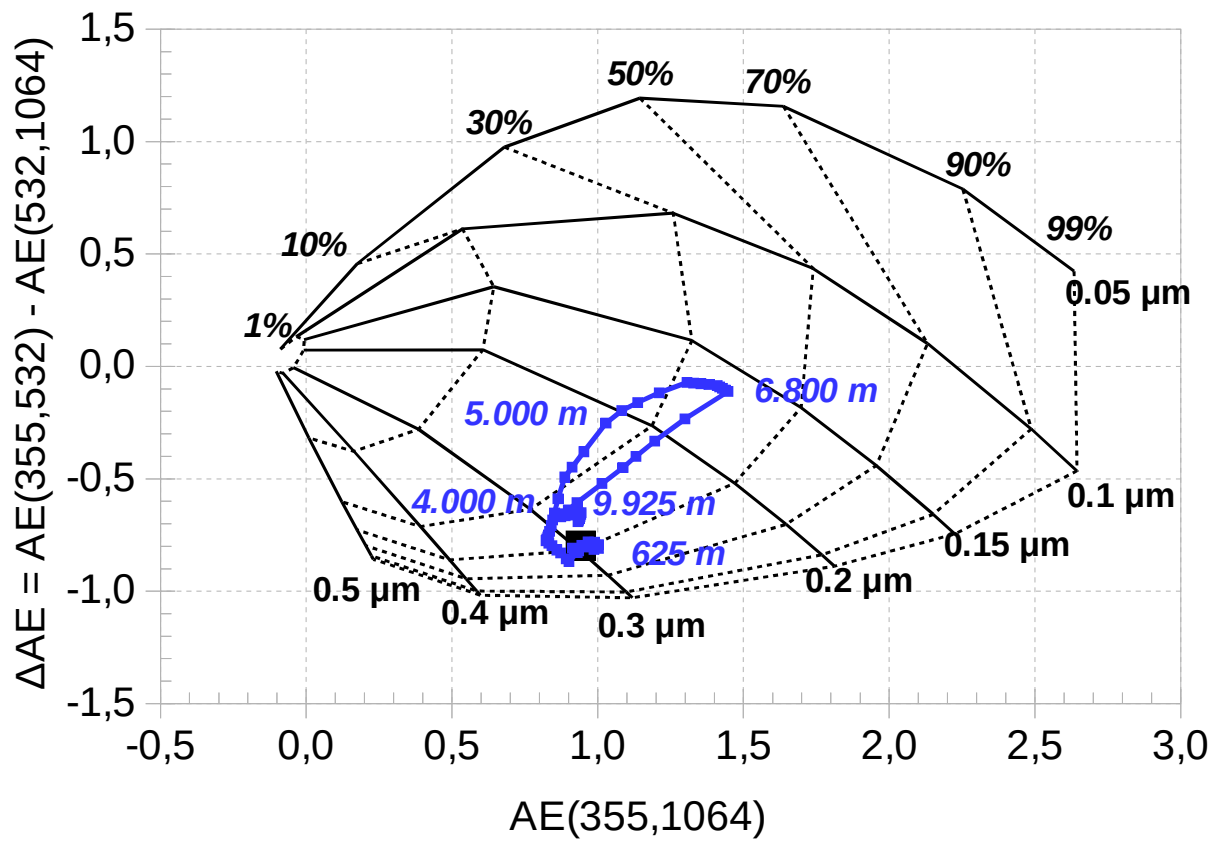

Fig. 12b Same as Fig. 11b for a constant-volume-fraction grid. 